\title{
IS LEGAL POSITIVISM TENABLE BEYOND MORAL RELATIVISM?**
}

\author{
¿ES DEFENDIBLE EL POSITIVISMO JURIDICO \\ MÁS ALLÁ DEL RELATIVISMO MORAL? \\ Miodrag JOVANOVIC $\hat{C}^{* *}$
}

\section{Resumen:}

En uno de sus estudios más recientes sobre las relaciones entre el derecho y moral, Alexy sostiene que uno de los principales argumentos contra cualquier tipo de no-positivismo es el referente al relativismo moral, argumento célebremente defendido por Kelsen. Dicho argumento rechaza la "tesis de la existencia" es decir, niega la existencia de elementos morales objetivos. Si el argumento es exitoso, dice Alexy, entonces el positivismo prevalece. En mi articulo no me detengo en discutir las condiciones sobre las cuales prevalece el positivismo sobre el no-positivismo. Más bien, discutiré si este argumento sobre el relativismo es clave para fundamentar una teoria positivista plausible. Para ello partiré de un punto común, a pesar de otros desacuerdos, entre todos los positivistas, es decir, la tesis de la separación, la cual sostiene que la validez de una norma no es ni conceptual ni necesariamente dependiente de ciertos estāndares morales asumidos. La plausibilidad de una teoria positivista se probará a partir de una comparación entre las teorias de Kelsen y Hart, los cuales eran relativistas morales. Sin embargo, mientras Kelsen fun-

* Artículo recibido el 14 de septiembre de 2014 y aceptado para su publicación el 24 de septiembre de 2014.

** Faculty of Law, University of Belgrade. Full Professor, e-mail: miodrag@ius.bg.ac.rs This paper was presented at the annual conference of the Central and East European Network of Jurisprudence The Challenges of the Contemporary Jurisprudence, which was organized from 13 to 16 September 2012 at the University of Sarajevo. I would like to thank to the participants of the conference, as well as, to Ken Himma, Bojan Spaic and Goran Dajović for their useful comements and criticisms. 
Este libro forma parte del acervo de la Biblioteca Jurídica Virtual del Instituto de Investigaciones Jurídicas de la UNAM

\title{
Miodrag JOVANOVIĆ
}

damenta su "Teoria Pura" abiertamente en el relativismo moral, Hart incorpora su noción de una "necesidad natural" lo cual significa una versión débil de realismo moral. Intentaré demostrar que en el caso de Hart es importante resaltar que cualquier desvío del relativismo moral resulta perjudicial para la defensa de la tesis de la separación, lo cual aplica para cualquier teoría positivista que directa o indirectamente incorpora el análisis de Alexy sobre la teoría de la existencia. Un enfoque alternativo que consideraré implica una reformulación de este debate tradicional en la teoría del derecho en el sentido de que las clasificaciones y etiquetas comunes a final de cuentas no resultan ser tan importantes y que la tesis de la separación podría no ser definitiva para la defensa de una teoria positivista

\section{Palabras clave:}

Positivismo jurídico, no-positivismo jurídico, relativismo moral, realismo moral, metodología de la filosofia del derecho.

\begin{abstract}
:
In one of the most recent articles on the relation between law and morality, Alexy claims that the central argument against any of the strands of legal non-positivism rests on the argument from moral relativism, famously advanced by Kelsen. This argument rejects the 'existence thesis', that is, it denies the existence of objective moral elements. If this argument stands, contends Alexy, 'then positivism prevails.' This paper will not dwell upon the question under what conditions, if any, legal positivism prevails over non-positivism. Instead, it will investigate whether the argument from relativism is not only central for refuting legal non-positivism, but is also of the key importance for grounding a tenable positivist theory. In doing so, it will proceed from the core thesis of legal positivism, which is, despite other disagreements, common for all authors covered by this theoretical label. This is the 'separation thesis', which states that legality of a norm is neither necessarily, nor conceptually dependent upon being in accordance with certain assumed moral standard. The tenability of a theory in the positivist tradition will be, more specifically, tested in light of the comparison of legal theories of Kelsen and Hart, who were both moral relativists. However, while Kelsen openly grounds his Pure Theory of Law in moral relativism, Hart's theory incorporates the teaching on 'natural necessity', which signifies the introduction of a 'thin' version of moral realism in the purportedly positivist account of law. If this paper succeeds in showing on Hart's case that even the slightest departure from moral relativism is detrimental for the sustainability of the 'separation thesis', then it will be assumed that this meta-ethical stance is in some important respects central for the grounding
\end{abstract}

\section{PROBLEMA}

Anuario de Filosofía y Teoria del Derecho,

Núm. 9, enero-diciembre de 2015, pp. 193-252 


\section{IS LEGAL POSITIVISM TENABLE BEYOND MORAL RELATIVISM?}

of a tenable theory in the positivist tradition. This conclusion would, consequently, have profound effects on the sustainability of all the positivist theories that directly or indirectly incorporate Alexy's 'existence thesis'. Moreover, if this analysis is correct, an alternative approach to the subject matter would imply no less than restating the terms of the traditional jurisprudential debate as to argue that classifying theories of law under different labels does not matter at all and/or that the 'separation thesis' is not definitional of a theory in the positivist tradition.

\section{Keywords:}

Legal Positivism, Legal Non-Positivism, Moral Relativism, Moral Realism, Jurisprudential Methodology. 


\title{
Miodrag JOVANOVIĆ
}

\begin{abstract}
Summary: I. Introduction. II. What Counts as 'Legal Positivism' and Does It Matter at All? III. What Constitutes a 'Tenable' Theory in the Positivist Tradition? IV. Kelsen: Grounding Legal Positivism in Moral Relativism. V. Hart: Legal Positivism and the 'Minimum Content of Natural Law'. VI. Contrasting Two Theories in the Positivist Tradition. VII. Conclusion. VIII. Bibliography.
\end{abstract}

\section{INTRODUCTION}

In a recent article, Alexy tries not only to draw a demarcation line between legal positivism and non-positivism, but also to classify different versions within both camps. ${ }^{1}$ In doing so, his initial premise is that the central argument against any of the strands of legal non-positivism rests on the argument from moral relativism, famously advanced by Kelsen. This argument rejects the 'existence thesis', that is, it denies the existence of objective moral elements. If this argument stands, contends Alexy, 'then positivism prevails. $^{2}$

This paper will not dwell upon the question under what conditions, if any, legal positivism prevails over non-positivism. Instead, it will investigate whether the argument from relativism is not only central for refuting legal non-positivism, but is also of the key importance for grounding a tenable positivist theory. Alexy does notice that one can accept the 'existence thesis' and, yet, remain a positivist, but he

1 Besides the familiar distinction between inclusive and exclusive positivism, Alexy distinguishes between exclusive non-positivism, as the strongest form of legal non-positivism; super-inclusive non-positivism, which maintains that legal validity is in no way affected by moral defects of legal rules; and inclusive non-positivism, which holds that moral defects undermine legal validity only in the cases of extreme injustice of legal rules. Alexy provides arguments in favor of the last version of legal non-positivism. Robert Alexy, 'Law, Morality, and the Existence of Human Rights' (2012) 25 Ratio Juris 2.

2 Ibid, 8. 
IS LEGAL POSITIVISM TENABLE BEYOND MORAL RELATIVISM?

does not offer any further explanation whether such a stance is theoretically more sustainable form of legal positivism than the one grounded in moral relativism. In what follows, I will contrast these two versions of positivism, by unpacking the broader question from the title of this paper in order to elucidate issues that seem to be hidden behind it.

\section{What Counts as 'Legal Positivism' AND Does It MatTer at All?}

In his harsh critique of Alexy's reply to legal positivism, ${ }^{3}$ Raz, among other things, charges the author with the misinterpretation of the 'separation thesis', as a plausible identifying marker of this strand of legal theory. ${ }^{4}$ In doing so, Raz makes a further point by saying that neither he cares whether his views are classified with legal positivism, as they commonly are, nor does he believe that the classification of legal theories as legal positivist or non-positivist is helpful after all. 5 However, he eventually concedes to the thesis, which is fairly 'successful in getting at the common core of the positivist tradition' and is 'possibly... common to all the theories' within this tradition. ${ }^{6}$ Its formulation belongs to Marmor and it states 'that determining what the law is does not necessarily, or conceptually depend on moral or other evaluative considerations about what the

3 Robert Alexy, The Argument from Injustice: A Reply to Legal Positivism (OUP 2002).

4 Joseph Raz, 'The Argument from Justice, or How Not to Reply to Legal Positivism', in The Authority of Law - Essays on Law and Morality (2nd edn, OUP 2009) 314ff.

5 Ibid, 317.

6 Instead of 'legal positivism', Raz speaks of 'theories in the positivist tradition'. He specifies that '[t]heories belong to a tradition by their frame of reference, sense of what is problematic and what is not, and by similar historical features which do not presuppose that they all share a central credo'.Ibid, 319. 
Este libro forma parte del acervo de la Biblioteca Jurídica Virtual del Instituto de Investigaciones Jurídicas de la UNAM www.juridicas.unam.mx

\section{Miodrag JOVANOVIĆ}

law ought to be in the relevant circumstances'. ${ }^{7}$ While this thesis seems to be a common denominator for various strands of legal positivism, they, nonetheless, disagree whether the identification of law ever requires the use of moral arguments or judgments about its merit. Those claiming that it does not are labeled as 'exclusivists', ${ }^{8}$ whereas their opponents are identified as 'inclusivists'. 9

7 Andrei Marmor, Positive Law and Objective Values (OUP 2001) 71.

8 Raz's 'sources thesis', which is a more stringent version of the 'separation thesis', states that 'the identification of law never requires the use of moral arguments or judgments about its merit'. Raz (n 4) 319. This stance does not imply denying that many moral principles are part of law, but only that 'a norm is never rendered legally valid in virtue of its moral content'. Marmor (n 7) 50.

9 Even though this stance is commonly associated with Coleman's work, in a series of recent papers this author challenges some of the main tenets of legal positivism, including those ascribed to 'inclusivism'. (Jules L. Coleman, 'Beyond the Separability Thesis: Moral Semantics and the Methodology of Jurisprudence' (2007) 27 OJLS 581; Jules L. Coleman, 'Beyond Inclusive Legal Positivism' (2009) 22 Ratio Juris 359). In his most recent piece, which is conceived as a rather ambitious project of reframing central questions and displacing conventional wisdom of jurisprudence, Coleman argues that the 'separability thesis' is neither the point of differentiation between legal positivism and natural law theory, nor is it compatible only with the former and not with the latter theoretical stance. In fact, 'legal positivism is compatible with either endorsing or rejecting the separability thesis', and, consequently, 'the separability thesis can hardly be an essential feature of positivism or otherwise definitional of it'. (Jules L. Coleman, 'The Architecture of Jurisprudence' (2012) 121 The Yale Law Journal 2, 33). Part of the reason for this contentious stance lies in the fact that Coleman proceeds from the reformulated 'separability thesis', which does not invoke the concept of legal validity (ibid 9). Coleman justifies this move, by claiming that validity is 'not a feature of law', but 'probably an artifact of jurisprudential theories' (ibid 8). This starting premise, however, is even more problematic, having in mind that temporal, spatial, material and personal spheres of validity of legal norms are of crucial importance for the daily functioning of legal practice. It seems, thus, that one can safely return to the non-reformulated 'separability thesis' (like Marmor's one), which invokes legal validity and, thus, still serves as a reliable marker of a theory in the positivist tradition. Other parts of Coleman's complex argumentation would have to be inves- 
IS LEGAL POSITIVISM TENABLE BEYOND MORAL RELATIVISM?

In a recent paper, Leiter investigates whether solving this problem of demarcation between the spheres of legal and moral validity actually matters. By drawing a parallel with a similar attempt in the philosophy of science to demarcate epistemically reliable forms of inquiry from unreliable ones, Leiter notices that the 'Demarcation Problem' in jurisprudence is also motivated by a theoretical dilemma -what is the nature of law- but practical concerns are even more pressing than in the case of science. Namely, the 'Demarcation Problem' in jurisprudence 'turns on the assumption that the moral validity of a norm entails a practical consequence, ie, it entails acting in accordance with the norm'. Under that assumption, confusing legal and moral validity may have serious practical consequences: 'it means that if the legal validity of a norm is equivalent to its moral validity, then every law ought to be obeyed. And, conversely, it means that if a norm is morally valid, then a legal actor ought to apply it.'10 Finally, the upshot of confusing legal and moral validity would also consist in a certain form of inaction - if a morally invalid norm is devoid of its legality, then a legal actor, particularly a legal official, ought not to apply it. ${ }^{11}$

Leiter argues that this problem might be circumvented by abandoning the theoretical aspiration to cut the normative world into legal and non-legal pieces, because, first, no successful analysis of the 'necessary' or 'essential' properties of human artifacts, including law, is ever possible; ${ }^{12}$ and, sec-

tigated in a separate inquiry and this, in any way, would be possible only after the announced publication of other two essays in the series.

10 Brian Leiter, 'The Demarcation Problem in Jurisprudence: A New Case for Skepticism' (2011) 31 OJLS 663, 670.

11 Whether moral invalidity of a norm has to be of a regular or extreme nature in order to strip the norm of its legal validity is the point of differentiation between what Alexy labels as exclusive and inclusive legal non-positivism. Alexy (n 1) 5-7.

12 Leiter (n 10) 669. One may argue that Marmor is heading in the same direction with his recent announcement of the farewell to conceptual analysis. In what is still a draft paper, Marmor argues, along the lines 
Este libro forma parte del acervo de la Biblioteca Jurídica Virtual del Instituto de Investigaciones Jurídicas de la UNAM www.juridicas.unam.mx

\section{Miodrag JOVANOVIĆ}

ond, the practical problems the Demarcation Problem might solve rarely arise in the ordinary cases, but in the extraordinary ones, where the demands of what seems paradigmatically to be law pull in one direction and the demands of what seem paradigmatically to be moral considerations pull in the other. ${ }^{13}$

Leiter, thus, suggests that we - judges, legal officers, citizens - should directly address the practical considerations of what ought to be done in particular cases, insofar as this problem 'is reducible to a psycho-social question about the attitudes people have about morality and legality.'14

Without entering here the discussion about plausibly weak points of Leiter's approach,15 his analysis demonstrates not only that the dispute concerning the nature of

with Dworkin, that conceptual analysis is not more than a linguistic inquiry of the meaning of words in a given context. However, he points out that Hartian strand of analytical jurisprudence should be seen not primarily as a project in conceptual analysis, but rather as a reductionist project, which aims to demonstrate that law can be reduced to social facts about people's conduct, beliefs and attitudes. Marmor, thus, does not abandon the method of determining essential properties of objects of inquiry. These properties are features 'of observable and learnable activities, not of language or concepts.' Hence, '[a] feature of a social practice is essential to it if without it the practice would either not have existed at all or would have been radically different from what it is'. Finally, since essential properties 'are neither a priori nor necessary', Marmor says that he sees 'no reason to deny that what is essential to a social practice is vague, allowing for some borderline cases'. Andrei Marmor, 'Farewell to Conceptual Analysis (in Jurisprudence)' in Wil Waluchow and Stefan Sciaraffa (eds.), Philosophical Foundations to the Nature of Law (OUP 2013), 209-229.

${ }_{13}^{13}$ Leiter (n 10) 676.

14 Ibid, 673.

15 A potential target of criticism would be Leiter's starting assumption that normativity of morals should be understood in exclusively psychological terms. That is, 'to the extent an agent's judgment that $\mathrm{X}$ is morally right has normative force for the agent, that normative force is explicable in terms of certain psychological facts about the agent'. Ibid, 671, 672 . 
IS LEGAL POSITIVISM TENABLE BEYOND MORAL RELATIVISM?

law is of everlasting theoretical interest, 16 but that it also might practically matter - at least in a number of borderline cases of, say, morally evil laws. ${ }^{17}$ According to Shapiro, these practical considerations fall under the 'Implication Question'. In asking this question, a legal theorist is not concerned with why something counts as an instance of law - this is the 'Identity Question' (which Leiter considers unanswerable within the project of conceptual analysis)'but rather with what necessarily follows or does not follow from that fact'. ${ }^{18}$ The 'Implication Question' comes to the fore especially in those extraordinary cases where legal and moral validity might seem to intersect. ${ }^{19}$

16 Leiter is, nonetheless, convinced that the dispute about the nature of law falls within the ambit of 'ultimately pointless disputes'. The persistence of such disputes, including the one on the 'Demarcation Problem', can be explained by the processes of professionalization and specialization of the respective disciplines, which 'always run the risk of generating both an audience and performers' for such disputes. Ibid 677 .

17 After all, it was exactly the experience of the Nazi state that revived the interest in challenging the main tenets of legal positivism, most notably in the post-War writings of Gustav Radbruch. His famous formula and its application by the German courts did not only affect vivid theoretical discussions in Germany, but it also triggered a much celebrated debate of the Anglo-American jurisprudence, that between Hart and Fuller. On Radbruch's formula, see eg Miodrag Jovanovi , 'Legal Validity and Human Dignity: On Radbruch's Formula' (2013) Archiv für Rechts- und Sozialphilosophie - Beihefte 137: 145-167. On the relevance of the Hart-Fuller debate for the contemporary jurisprudential disputes, see, Peter Cane (ed), The Hart-Fuller Debate in the 21st Century (Hart Publishing 2010).

18 Scott J. Shapiro, Legality (The Belknap Press of Harvard University Press 2011) 12 .

19 Shapiro's argument, at first, seems to be far broader, when claiming that 'analytical jurisprudence has profound practical implications for the practice of law', insofar as 'the answer to what the law is in any particular case depends crucially on the answer to what is law in general' (idem 25.). However, he later on clarifies that this does not imply that it is impossible to answer any practical legal question without the philosophical inquiry into the nature of law, because, most often, this is possible. Moreover, in a number of practical issues, the archetypical rival theories of legal positivism and natural law will give the same answer. However, 'the answers to 


\section{Miodrag JOVANOvić}

Accordingly, it still very well makes sense to ask which theoretical view about the nature of law can count as an instance of legal positivism (or legal non-positivism for that matter). This, then, takes us back to an attempt to establish some core thesis of legal positivism, which is, despite other disagreements, common for all authors covered by this theoretical label. ${ }^{20}$ The aforementioned Marmor's formulation of the 'separation thesis' might serve this purpose.

\section{What Constitutes a 'Tenable' Theory IN THE POSITIVIST TRADITION?}

It should be clear from the outset that the word 'tenable' in the title of this paper stands for 'theoretically defensible' or 'theoretically successful'. Then, the problem boils down to the question of determining criteria of 'defensible' or 'successful' theoretical position in jurisprudence. This is certainly not an easy task. Part of the reason for being so lies in the fact that some of the critical meta-theoretical questions are not that often tackled in jurisprudential treatises. Apart from the one already mentioned, Julie Dickson refers to a number of other issues that 'are frequently left unanswered.' For instance, On what basis do and/or should we adjudicate between rival jurisprudential claims, and/or the theories which make those claims? Are the aims of a theory of law descriptive, or critical, or justificatory with regard to its explanandum? Are any or all of these approaches mutually antagonistic, or could, for example, a descriptive approach to legal theory be compatible with a justificatory ac-

some questions do depend on which view about the nature of law is correct. And in these cases, knowing the nature of the law is indispensable'. (Ibid 31).

20 As rightly pointed out by Gardner, 'there is nothing philosophical to say about "legal positivists" as a group unless there is some distinctive proposition or set of propositions that was advanced or assumed by all of them'. John Gardner, 'Legal Positivism: 51/2 Myths' (2001) 46 The American Journal of Jurisprudence 199. 
IS LEGAL POSITIVISM TENABLE BEYOND MORAL RELATIVISM?

count of the nature of law? Is there a correct method via which law should be understood in order to achieve one or more of the aims mentioned above? 21

Having in mind the aspiration of this paper, it is obvious that many of the enumerated questions will not be addressed here either. The one that is in the focus of my attention is, nevertheless, directly connected to the established core thesis of legal positivism. This means that other plausible approaches to the subject matter will not be discussed in more detail.22 Consequently, how 'tenable' i.e. theoretically successful/defensible is one theory in the positivist tradition will be measured against Marmor's definition of the 'separation thesis'. This thesis of legal positivism tells us 'how the concept of law is to be defined'. It formulates 'the result of a line of reasoning without giving voice to the arguments behind it'. ${ }^{23}$ Every positivist has to defend the aforementioned version of the 'separation thesis' if his theory is to be labeled as the one in the positivist tradition. Yet, this thesis is only a minimum common denominator of all the theories in the positivist tradition, and they may greatly vary —as they actually do - in providing arguments for sticking to it.

Accordingly, it is possible to differentiate between the two roles of the 'separation thesis'. On the one hand, it serves a

21 J. Dickson, Evaluation and Legal Theory (Hart Publishing 2001).

22 For instance, Shapiro uses the so-called 'Possibility Puzzle', which concerns the question of how is law possible, to assess the theoretical sustainability of different jurisprudential approaches. He presents this puzzle in the form of the chicken/egg dilemma, where the Egg principle states that no body can exercise power to create legal norms, unless it is authorized to do so by an already existing legal norm, while the Chicken principle states that any legal norm conferring power for the creation of legal norms can exist only if it was created by some body with power to do so. Using this criterion, one is able to differentiate between theories in the positivist tradition. Whereas Austin's theory famously endorsed the Chicken principle, Hart's approach paradigmatically defended the Egg principle, etc. Shapiro (n 18) 40, 43-44.

23 Alexy (n 3) 20. 


\section{Miodrag JOVANOVIĆ}

meta-theoretical function of delineating a theory of law in the positivist tradition and, thus, distinguishing it from a rival stance of natural law theory (legal non-positivism). This is what Coleman considers as one of the central 'conventional wisdoms' of contemporary jurisprudence. It rests on the three interrelated, yet separate claims: the 'separation thesis' is essential to legal positivism; it distinguishes legal positivism from natural law theory; it does so, on account that it is both essential for the former and incompatible with the latter. ${ }^{24}$

On the other hand, the 'separation thesis' has its place among substantive arguments about the nature of law. To be sure, merely endorsing this thesis is far from having a comprehensive theoretical exposition of law in the positivist tradition. Consequently, all the major theories in this tradition essentially rely on some other arguments/concepts as substantively more important, and eventually, as more definitional of their positivist accounts. Such a role is designated to the concept of 'command' in Austin's theory of law; or to the 'basic norm' in Kelsen's theory; or to the 'rule of recognition' in Hart's theory; or to the 'authority' in Raz's theory; or to the 'plan' in Shapiro's theory, etc. Hence, one may say that the 'separation thesis' is necessary, but not sufficient condition for the construction of a sustainable theory of law in the positivist tradition. That is, in all the positivist accounts of law it necessarily plays some role, and is as such incorporated in and intricately connected to the complex net of substantive arguments, including those that are deemed central for the given theory. Yet, it is commonly possible to identify the background theoretical reasons and/or motives for endorsing the 'separation thesis'. Thus, in the rest of the paper I will primarily focus on these background reasons, thereby trying to assess the 'tenability' of a theory in the positivist tradition.

24 Coleman, 'The Architecture of Jurisprudence' (n 9) 6. As already pointed out, Coleman tries to refute all three claims. 
IS LEGAL POSITIVISM TENABLE BEYOND MORAL RELATIVISM?

More specifically, the 'separation thesis', in both of its formulations, revolves around an attempt to set the boundaries of relationship between legality and morality. That is, this attempt "concerns concept formation at the most fundamental level in the study of law: How should we understand and shape the concept of law? And what role, if any, should moral considerations play in such concept formation?'25 Since meta-ethics is a philosophical discipline that concerns 'higher-level reflection on the nature of moral talk and moral thought', ${ }^{26}$ I will investigate whether successfulness of the core thesis of legal positivism is dependent upon a particular background meta-ethical stance. ${ }^{27}$

That this approach is not unwarranted is witnessed by occasional statements regarding the presumably most adequate meta-ethical standpoint of theories in the positivist tradition. Hence, Leiter notices that ' $\mathrm{t}$ ] he early Kelsen and Hart had (or at least often appeared to presuppose) what seems to me to be the correct meta-ethical position (broadly anti-realist and non-cognitivist)'. ${ }^{28}$ Spaak makes a much

25 Torben Spaak, 'Kelsen and Hart on the Normativity of Law' (2005) 48 Scandinavian Studies in Law 397, 398.

26 Philip Pettit, ‘Substantive Moral Theory' (2008) 25 Social Philosophy and Policy 1.

27 Pettit notices that there are three interrelated meta-ethical questions. The first one concerns the question of whether moral predications have truth conditions (the cognitivism question). Second, 'If moral predications are truth-conditional, do they predicate real, bona fide properties, so that their truth conditions are routinely fulfilled?' (the realism question). Finally, 'If the moral properties predicated are bona fide in character, do they answer to our intuitions about the character of moral properties-intuitions to the effect that they are not just properties of our subjective reactions, for example, and not properties that are relative to a variable framework, cultural or otherwise?' (the objectivism question). ibid $1-2$.

28 He specifies that "Kelsen's jurisprudence bears the stamp of NeoKantianism and the moral anti-realism common among logical positivists, while Hart's jurisprudence reflects the methodological influence of ordinary language philosophy and the substantive influence of post-World War II Oxford-style non-cognitivism.” Leiter (n 10) 666. 


\section{Miodrag JOVANOVIĆ}

stronger claim, arguing that '[u]nderlying, though neither entailing nor entailed by, legal positivism is metaethical noncognitivism, according to which moral claims have no cognitive meaning'. ${ }^{29}$ On the other side of the spectrum are those advancing the so-called 'irrelevance thesis'. It is crucial for this thesis that it is not premised on rejecting one meta-ethical position, say, objectivism, and embracing the contrary stance, say, relativism. Quite the contrary, 'the idea is that the very question of ethical objectivity, and so either way of responding to it, is devoid of consequences for law'. 30 This stance is most famously advanced by Waldron, who argues that 'legal positivism is meta-ethically neutral. It takes no position on the nature of moral judgement. It is compatible with moral realism and with moral anti-realism'. ${ }^{31}$ Green develops a similar argumentation. He says that "[t]o say that the existence of law depends on facts and not on its merits is a thesis about the relation among laws, facts, and merits, and not otherwise a thesis about the individual relata'. Consequently, 'most traditional "natural law" moral doctrines -including the belief in a universal, objective morality grounded in human nature- do not contradict legal positivism'. ${ }^{32}$

29 Spaak (n 25) 399.

30 John Tasioulas, 'The Legal Relevance of Ethical Objectivity' (2002) 47 The American Journal of Jurisprudence 211, 212.

31 Jeremy Waldron, 'The Irrelevance of Moral Objectivity', in Robert P George (ed.), Natural Law Theory - Contemporary Essays (OUP 1992) 161. It is important to stress that Waldron also proceeds from the 'separation thesis' as definitional of a theory in the positivist tradition. He says that, according to the positivist conception of law, 'statements about what the law is - whether in describing a legal system, offering legal advice, or disposing of particular cases - can be made without exercising moral or other evaluative judgement'. Ibid 160.

$32 \mathrm{He}$ states furthermore that ' $\mathrm{t}]$ he only influential positivist moral theories are the views that moral norms are valid only if they have a source in divine commands or in social conventions. Such theists and relativists apply to morality the constraints that legal positivists think hold for law'. Leslie Green, 'Legal Positivism', in Edward N. Zalta (ed.), The 
IS LEGAL POSITIVISM TENABLE BEYOND MORAL RELATIVISM?

In the remaining sections, I will investigate whether moral relativism is indeed of the critical importance for advancing a theory in the positivist tradition, or the 'separation thesis' of legal positivism can be defended irrespective of the background meta-ethical theory. I will do so by contrasting legal theories of Kelsen and Hart. As noticed, both are perceived as moral relativists. However, while Kelsen openly grounds his Pure Theory of Law (Reine Rechtslehre) in moral relativism, Hart's theory incorporates the teaching on 'natural necessity', which signifies the introduction of a 'thin' version of moral realism in the purportedly positivist account of law. If I manage to demonstrate on Hart's case that even the slightest departure from moral relativism is detrimental for the sustainability of the 'separation thesis', then I will assume that this meta-ethical stance is in some important respects central for the grounding of a tenable theory in the positivist tradition. This conclusion would, consequently, have profound effects on the sustainability of all the positivist theories that directly or indirectly incorporate Alexy's 'existence thesis'.

\section{Kelsen: Grounding Legal Positivism in Moral Relativism}

Even though moral philosophy differentiates between several versions of moral relativism, ${ }^{33}$ this meta-ethical doctrine amounts to the thesis that moral right and wrong, that is, good and bad, justice and injustice, etc., are always

Stanford Encyclopedia of Philosophy (Winter 2003 Edition) http:// plato. stanford.edu/entries/legal-positivism/ accessed 5 February 2013.

33 Harman, for instance, speaks of the three versions of moral relativism. 'Normative moral relativism' states that 'different people, as agents, can be subject to different ultimate moral demands'. 'Moral judgment relativism' says that 'moral judgements make implicit reference to the speaker or to some other person or to some group or to one or another set of moral standards, etc." Finally, 'Meta-ethical relativism' asserts that 'conflicting moral judgements about a particular case can both be right'. Gilbert Harman, 'What is Moral Relativism?' in Explaining Value and Other Essays in Moral Philosophy (Clarendon Press 2000) 20. 


\section{Miodrag JOVANOVIĆ}

relative to a choice of moral framework. What is morally right, good, and just in relation to one moral framework can be morally wrong, bad, and unjust in relation to a different moral framework. Thus, 'no moral framework is objectively privileged as the one true morality'. ${ }^{44}$ Consequently, in order to make sense and be defensible, moral appraisals of actions have to be understood not as judgments about what is right or wrong absolutely.

As already noted, some authors argue that legal positivism largely entails moral non-cognitivism, and Leiter contends that Kelsen and Hart 'were both metaphysical anti-realists about moral norms: that is, they denied that such norms had any objective existence'. 35 Put differently, they were, according to Leiter, moral non-cognitivists. ${ }^{36}$ Meta-ethical stance of moral non-cognitivism implies that moral statements have no truth conditions. When uttering sentences, like ' $\mathrm{X}$ is morally wrong', people do not normally express beliefs, where beliefs are understood as some propositional attitudes. Phrases, like the one aforementioned, do not denote facts about the world, but are more similar to statements of approval or disapproval. While it is often implied that moral non-cognitivism has much in common with various strands of meta-ethical relativism, this need not be the case. ${ }^{37}$

34 Gilbert Harman, 'Moral Relativism' in Gilbert Harman and Judith Jarvis Thomson, Moral Relativism and Moral Objectivity (Blackwell Publishers 1996) 3.

35 Leiter (n 10) 671.

36 Some moral philosophers argue that we should differentiate between moral anti-realists who hold that moral facts do not exist at all (non-cognitivists) and those who argue that their existence depends on the beliefs and desires of human beings (idealists or constructivists). David Owen Brink, Moral Realism and the Foundation of Ethics (Cambridge University Press 1989) 18.

37 As noticed by van Roojen, some non-cognitivists 'claim that whether or not a moral judgment is mistaken is itself a matter for moral theorizing. A speaker should only call a moral judgment true if he or she accepts that judgment. A speaker who expresses his or her acceptance of relativism in 
IS LEGAL POSITIVISM TENABLE BEYOND MORAL RELATIVISM?

In his attempt to establish the Pure Theory of Law, Kelsen can be said to endorse moral relativism, but it is less clear whether non-cognitivism can be attributed to him as well. Kelsen's project of 'purifying' the theoretical exposition of law has two simultaneous tasks. First is to secure the autonomy of the subject of one such discipline, and the second is to establish its genuine methodological apparatus. Both tasks are intertwined though. On the one hand, Kelsen notices that the 'purity' of the theory of law amounts to 'the independence of the law as an object of scientific cognition'. ${ }^{38}$ On the other hand, the 'purity' of legal theory is equated with the absence of 'mixture' of different scientific methods as applied in the study of law. ${ }^{39}$ Meta-ethical arguments play their role in completing both of the tasks of the 'purification' project.

In trying to secure the autonomy and self-standing nature of the subject of its investigation, the 'purified' legal theory must be 'restated as not only striving to defend the irreducible normativity of law against any construction denying its specificity and restating it in moral or factual terms.' Moreover, Kelsen's project 'also rejects any attempt

the normal way would then seem to be expressing commitment to a very deferential moral theory. What seems to be a higher level metaethical claim that no consistent set of moral judgments is mistaken, is really just another moral judgment and hence one which would be rejected by any moral judge with substantive moral commitments'. Mark van Roojen, 'Moral Cognitivism vs. Moral Non-Cognitivism' in Edward N Zalta (ed), Stanford Encyclopedia of Philosophy (Summer 2009) ?http://plato.stanford.edu/entries/moral-cognitivism/\#NonRel? accessed 5 February 2013.

38 Hans Kelsen, "Foreword" to the Second Printing of Main Problems in the Theory of Public Law' in Stanley L Paulson and Bonnie Litschewski Paulson (eds), Normativity and Norms - Critical Perspectives on Kelsenian Themes (Clarendon Press 1998) 3.

39 Kelsen emphasizes that his theory is 'pure', insofar as 'it wishes to avoid the uncritical mixture of methodologically different disciplines (methodological syncretism) which obscures the essence of the science of law and obliterates the limits imposed upon it by the nature of its subject matter'. Hans Kelsen, Pure Theory of Law (Max Knight tr, University of California Press 1967) 1. 


\section{Miodrag JOVANOVIĆ}

to explain this normativity by reference to moral or factual considerations.' 40 Hence, the Pure Theory of Law has, first, to distance itself from the natural law teaching. It will do so by denying the dual nature of its subject, that is, the duality of positive and natural law, as claimed by the rival theory. Traditional natural law theories hold that natural law is an ideal, unchangeable law, which is identical to justice. Its precepts are inherent in the nature (of God, human, things), but not the one belonging to empirical reality. It is the transcendental nature that serves as the ultimate source of natural law precepts of just behavior. ${ }^{41}$ The duality of the subject of jurisprudence has to be repudiated not only because natural law teaching implies transcendental 'metaphysical speculation' as the method of research, ${ }^{42}$ but also because justice is not an absolute, but a relative value. ${ }^{43}$

The second adversary of the 'purified' legal theory is an approach that tends to reduce legal norms to social facts. More particularly, this approach confuses the reality of legal norms with the reality of empirical facts. Kelsen's refutation of this approach consists in taking "the "ought" as the expression for the autonomy of the law ... in contradistinction to a social "is" that can be comprehended "sociologically". Since the subject of legal theory is positive law, as a normative order, '[t]he norm qua ought-judgment' is, in the next step, 'contrasted with the law of nature, and the reconstructed legal norm (Rechtsaatz), understood as a norm qua ought-judgment, is contrasted with the law of causality that is specific to sociology'. ${ }^{44}$ In describing positive law as

40 Sylvie Delacroix, Legal Norms and Normativity - An Essay in Genealogy (Hart Publishing 2006) 31.

41 Hans Kelsen, 'Naturrechtslehre und Rechtspositivismus' in Friedrich Koja (ed), Hans Kelsen oder Die Reinheit der Rehtslehre (Böhlau Verlag 1988) 232.

42 Ibid, 231.

43 Ibid, 242.

44 Kelsen (n 39), 4-5. 
IS LEGAL POSITIVISM TENABLE BEYOND MORAL RELATIVISM?

its subject of study, legal theory uses the principle of 'imputation' (Zuschreibung) in analogous way as natural sciences use the principle of causality to describe nature, or sociology to describe human society. ${ }^{45}$

The autonomy of the subject of jurisprudence has to be safeguarded with its genuine methodology. It is generally acknowledged in the literature that Kelsen 'placed essential reliance on epistemological arguments in defending legal positivism'. ${ }^{46}$ Kelsen's inclination to establish jurisprudence as 'the specific science of law' implies adopting the scientific method of empirical positivism. For Kelsen, '[s]cience is the product of cognition expressed in sentence describing an object; cognition is directed at truth; it can not constitute moral or political values'. 47 That way, the Pure Theory of Law, that is, legal positivism, establishes itself as 'a realistic' legal theory in opposition to the natural law theory, as 'an idealistic' and metaphysical one. ${ }^{48}$ This is the first methodological pillar of the 'purification' project.

The second one stems from a more basic posture of the neo-Kantian philosophy, which draws the sharp division between what 'is' (Sein) and what 'ought to be' (Sollen). These two worlds, divided by 'an unbridgeable gap', ${ }^{49}$ generate the respective distinction between the normative and ex-

45 Whereas ' $\mathrm{t}$ ] he principle of causality states: If there is A, there is (or will be) B. The principle of imputation states: If there is A, there ought to be B'. Hans Kelsen, 'Causality and Imputation' (1950) 61 Ethics 1, 6.

46 Stefan Hammer, 'A Neo-Kantian Theory of Legal Knowledge in Kelsen's Pure Theory of Law? in Paulson and Litschewski Paulson (eds) (n 40) 177. cf Wolfgang Kersting, 'Neukantianische Rechtsbegründung. Rechtsbegriff und richitges Recht bei Cohen, Stammler und Kelsen' in Robert Alexy and others (eds), Neukantianismus und Rechtsphilosophie (Nomos 2002) 59.

47 Hans Kelsen, 'Politics, Ethics, Religion and Law' in Gerhard A Ritter and Gilbert Ziebura (eds), Faktoren der politischen Entscheidung Festgabe für Ernst Fraenkel zum 65 Geburtstag (Walter de Gruyter \& Co 1963) 6.

48 Kelsen (n 41) 231.

49 H. Kelsen, Hauptprobleme der Staatsrechtslehre (JCB Mohr 1911) 8. 
Este libro forma parte del acervo de la Biblioteca Jurídica Virtual del Instituto de Investigaciones Jurídicas de la UNAM www.juridicas.unam.mx

\section{Miodrag JOVANOVIĆ}

plicative sciences. ${ }^{50}$ Jurisprudence falls in the former category, not in the sense that it itself is 'a law-setting authority' (rechtsetzenden Gewalt), but because its object is the world of norms (Sollen), and not the world of social reality. ${ }^{51}$ However, in order to remain scientific, jurisprudence has to be 'an analysis free of all ethico-political value judgments'. ${ }^{52}$ This, furthermore, implies differentiating between jurisprudence, as a science of law, and legal politics. Whereas the former 'attempts to answer the question what

50 Hans Kelsen, Grenzen zwischen juristischer und soziologischer Methode (JCB Mohr 1911) 10.

51 'If jurisprudence is to present law as a system of valid norms, the propositions by which it describes its object must be "ought" propositions, statements in which an "ought", not an "is", is expressed. But the propositions of jurisprudence are not themselves norms ... The jurist, as the theoretical exponent of the law, presents these norms in propositions that have a purely descriptive sense, statements which only describe the "ought" of the legal norm. It is of the greatest importance clearly to distinguish between legal norms which comprise the object of jurisprudence and the statements of jurisprudence describing that object.' Hans Kelsen, 'The Pure Theory of Law and Analytical Jurisprudence' (1941) 55 Harvard Law Review 44, 51. After meeting Kelsen in November 1961 at the Berkley Law School, Hart reported that one of the points that he had wanted to discuss with him was exactly this author's expression 'Rules of law in a descriptive sense'. What puzzled Hart was Kelsen's methodological claim that while explicating and analyzing the existing law, the Pure Theory of Law still falls within the category of 'normative sciences'. However, in the subsequently published paper that summarizes their discussion, Hart seems to grasp more fully into Kelsen's methodological apparatus. Hence, he eventually states: 'I do not think his terminology of rule and ought "in a descriptive sense" happy, but I do think he was wise to reject the alternative I proffered'. Herbert Hart, 'Kelsen Visited' (1963) 10 UCLA Law Review 709, 716-17. In the translation of Kelsen's 'Foreword' to the 2 nd edition of his Hauptprobleme, Paulson stresses that he prefers Eugenio Bulygin's phrase 'reconstructed legal norm' for Kelsen's Rechtsaatz to the phrase 'rule of law', used by the English translator of his Allgemeine Theorie. (Kelsen (n 40) 4, fns 1, 5) Kelsen himself, however, used the phrase 'rule of law' in a number of papers published in English.

52 Hans Kelsen, Introduction to the Problems of Legal Theory (translation of the first edition of the Reine Rechtslehre, by BL Paulson and SL Paulson) (Clarendon Press 1992) 53. 
IS LEGAL POSITIVISM TENABLE BEYOND MORAL RELATIVISM?

and how the law is', the latter is focused on the question 'how it ought to be'. ${ }^{53}$ Understood as a normative science of law, in the aforementioned sense of the word, jurisprudence, finally, has to be distinguished from 'sociological jurisprudence'. Whereas the former is the inquiry how people ought to behave according to law, the latter is the study how people actually behave. ${ }^{54}$

The third methodological pillar of Kelsen's theory is meta-ethical stance of moral relativism. It plays a crucial role in defending legal positivism. Beyleveld and Brownsword illustrate this feature of the 'purification' project in the following way: 'Kelsen argues that moral relativism is correct. Consequently, Natural Law Theory (Objectivistic Legal Idealism) is incorrect, and therefore Legal Positivism is correct.'55 Ultimately, Kelsen 'defines Legal Positivism as the denial of Objectivistic Legal Idealism'.56 This, furthermore, implies that jurisprudence qua science of law has to be methodologically differentiated from the philosophy of justice, because justice is a value, and value judgments are in the last instance subjective and relative.

53 Kelsen (n 39), 1.

54 While admitting of the disciplinary sustainability of 'sociological jurisprudence', Kelsen was very critical of the American school of Legal Realism, as an exposition of this disciplinary approach. He also criticized Austin for introducing sociological elements in his analytical jurisprudence. Eventually, Kelsen concludes that '[w] hat goes under the name of sociological jurisprudence is hardly more than methodological postulates'. However, there are special sociological issues related to law. One of them is belief in justice, which we commonly find among those who create, apply and obey the law. This issue is 'a proper subject for sociological jurisprudence; perhaps even its specific subject'. Hans Kelsen, General Theory of Law and State (Harvard University Press 1949) 174.

55 Deryck Beyleveld and Roger Brownsword, 'Methodological Syncretism in Kelsen's Pure Theory of Law' in Paulson and Litschewski Paulson (eds.) (n 40) 133.

56 Ibidem 134. These two authors argue that Kelsen eventually espouses what they label as 'Relativized Legal Idealism'. However, this is not a warranted conclusion. I will return to their criticism of Kelsen's methodology in the sixth part of the paper. 


\section{Miodrag JOVANOvić}

Kelsen says that justice is a social phenomenon, the product of a society, and hence different according to the nature of the society within which it arises'. Given the great national, religious, professional, etc. diversity of humanity, 'there are a great many very different ideas of justice; too many for one to be able to speak simply of justice'. ${ }^{57}$ Adopting value relativism does not imply, however, 'that there are no values and, particularly, that there is no justice'. It only means that values, including justice, are relative and not absolute, "that the values as established by our norm-creating acts cannot claim to exclude the possibility of opposite values'. ${ }^{8}$ Consequently, a 'purified' theory of law 'in no way opposes the requirement for just law by declaring itself incompetent to answer the question whether a given law is just or not'. Its incompetence stems from the nature of the question - it 'cannot be answered scientifically at all'.59 Consequently, the Pure Theory of Law knows of no 'problem of totalitarianism' (das Totalitarismusproblem) ${ }^{60}$ or the 'Hitler problem' (das Hitler-Problem) ${ }^{61}$, which were designations, used by some German authors, to denote the problem of validity of morally wicked laws in the Nazi Germany. ${ }^{62}$

The standpoint of the Pure Theory of Law with respect to the issue of (un)just, (im)moral laws and, consequently, to the 'separation thesis', is exemplified in the following passage:

57 Kelsen (n 54), 8.

58 Kelsen (n 39), 67.

59 Kelsen (n 54), 6.

60 Bernd Rüthers, Rechtstheorie (3rd edn, CH Beck 2007) 214.

61 Klaus F. Röhl, Allgemeine Rechtslehre (Carl Heymanns Verlag 2001) 302.

62 'From the standpoint of science, free from any moral or political judgments of value, democracy and liberalism are only two possible principles of social organization, just as autocracy and socialism are. There is no scientific reason why the concept of law should be defined so as to exclude the latter'. Kelsen (n 54) 5. 
IS LEGAL POSITIVISM TENABLE BEYOND MORAL RELATIVISM?

The postulate, made under the supposition of a relativistic theory of value, to separate law and morals and therefore law and justice, merely means this: (1) If a legal order is judged to be moral or immoral, just or unjust, these evaluations express the relation of the legal order to one of many possible moral systems but not to 'the' moral system and therefore constitute only a relative, not an absolute, value judgment; and (2) the validity of a positive legal order does not depend on its conformity with some moral system. ${ }^{63}$

As a result, '[1]egal norms may have any kind of content. There is no kind of human behavior that, because of its nature, could not be made into a legal duty corresponding to a legal right'. This is so, because the legal validity of a norm 'cannot be questioned on the ground that its contents are incompatible with some moral or political value'. ${ }^{64}$

Values involved in judgments to the effect that something is just or unjust, moral or immoral, are 'values of justice'. On the other hand, those involved in judgments to the effect that something is lawful or unlawful are values of law'. ${ }^{65}$ Judgments, attributing the latter qualities to some human behavior, can be also called juristic value judgments'. Kelsen says that they are 'true or false, and their truth or falsehood may be tested', insofar as one can 'point to a legal rule referring, affirmatively or negatively, to the behavior in question'.66 This, then, means that 'juristic value judgments' presuppose the existence of a norm, of an 'ought'. ${ }^{67}$ Kelsen rejects the interest theory of value, which would imply equating the judgment asserting the existence of a legal norm with the judgment asserting the existence of

63 Kelsen (n 39) 66-67.

64 Kelsen (n 54) 113.

65 Hans Kelsen, 'Value Judgments in the Science of Law' in What is Justice? Justice, Law, and Politics in the Mirror of Science (University of California Press 1971) 209.

66 Ibid, 210.

67 Ibid, 211. 


\section{Miodrag JOVANOVIĆ}

an interest. 68 This fallacy stems from the erroneous identification of the legal norm and the act by which it is created. Nevertheless, a legal norm is the specific meaning of an act, called 'a norm-creating act'. 'Positiveness' of law is consisted in the fact that ' $[t]$ he existence of a legal norm can be affirmed only if an act has occurred the meaning of which is a legal norm'. ${ }^{69}$

Although the existence of every norm is conditioned by a certain fact, the reason for its validity can be found only in some other, higher norm, because no 'ought' can be inferred from 'is'. The chain of validity ends with the presupposed 'basic norm' (Grundnorm), which can be revealed by an analysis of juristic thinking. This hypothetical basic norm is the foundation of all juristic value judgments possible within the frame of the legal order of a given state'.70 Though it is the presupposition of the juristic thinking, the basic norm is by no means arbitrary. Namely, jurists consider a constitution as valid only when the legal order based on it is by and large effective. Accordingly, the juristic thinking assumes the principle of effectiveness of the legal order as a whole whenever acknowledging a norm or a set of norms as valid. ${ }^{71}$ The effectiveness of the legal order as whole is, thus, 'a condition' of validity of each and every legal norm. ${ }^{72}$

68 Ibid, 212.

69 Ibid, 214.

70 'If the historically first constitution, and the norms issued on this basis, are to be considered as legally binding norms, then a norm must be presupposed to the effect that one ought to behave in conformity with the historically fist constitution" (ibidem, 221). Without the presupposed basic norm, we would lack the standard to assess certain behavior as lawful or unlawful, and, hence, '[t]he value judgment that the creation of the first constitution is legal, is the necessary foundation for all other juristic value judgments'. Ibid, 223.

71 Ibid, 224.

72 In turn, each and every norm of a system need not be effective in order to be rendered valid, as long as the system as a whole is by and large effective. Ibid, 225. 
IS LEGAL POSITIVISM TENABLE BEYOND MORAL RELATIVISM?

A juristic value judgment, attributing lawfulness or unlawfulness to a certain behavior, implies the assertion of the existence of a given norm. The existence (i.e. validity) of a norm is different from the existence of a fact, but, being conditioned by definite facts, the existence of a legal norm can ' - indirectly - be verified in an objective way by demonstrating the existence of these facts: the effectiveness of the total legal order to which the norm belongs and the presence of the fact "creating" the norm.' Insofar as the objective verification of juristic value judgments is possible, 'the value of law is an objective value'. ${ }^{73}$

The same cannot be said of the 'value of justice', despite the fact that judgments stating that something is just or unjust claim to affirm an objective value. This is so, because the norms which are actually used as standards of justice vary from individual to individual. ${ }^{74}$ Whereas no 'unique standard of justice' exists, there exists 'only one positive law', and '[i]ts contents can be unambiguously ascertained by an objective method'. Kelsen's final statement regarding the difference between 'values of law' and 'values of justice', as well as between legal norms and moral norms (of justice), reveals that meta-ethical stance of moral non-cognitivism can be eventually attributed to him:

The existence of the values of law is conditioned by objectively verifiable facts. To the norms of positive law there corresponds a certain social reality, but not so to the norms of justice. In this sense, the value of law is objective, while the value of justice is subjective ... Juristic value judgments are judgments that can be tested objectively by facts. Therefore

73 The value of law is objective in another sense as well. If the values of law, such as 'lawfulness', can be assessed by demonstrating a certain relation between the legal norm and behavior, then a behavior is not valuable only for a certain individual - "behavior is lawful or unlawful "for everybody", just as a thing is heavier or lighter than air "for everybody".' Ibid, 226.

74 Kelsen believes that, in this respect, the interest theory of value may be applied to 'values of justice'. Ibid 228. 


\section{Miodrag JOVANOVIĆ}

they are admissible within a science of law. Judgments of justice can not be tested objectively. Therefore a science of law has no room for them. Judgments of justice are moral or political value judgments... They intend to express an objective value... They presuppose a norm which claims to be objectively valid. But the existence and contents of this norm can not be verified by facts. It is determined only by a wish of the subject making the judgment. ${ }^{75}$

\section{Hart: Legal Positivism And the 'Minimum CONTENT OF NATURAL LAW'}

The 'separation thesis' has a prominent place in Hart's theory of law. Moreover, for him, this thesis is definitional of legal positivism. At the beginning of the Chapter IX of his The Concept of Law, which is dedicated to the elucidation of the relation between laws and morals, Hart says that "we shall take Legal Positivism to mean the simple contention that it is in no sense a necessary truth that laws reproduce or satisfy certain demands of morality, though in fact they have often done so".76 Put differently, identifying what counts as a legal rule does not necessarily, nor conceptually require resorting to morality. Regarding the existence or content of law, the connection between law and morality is only of the contingent nature. ${ }^{77}$

Hart's standpoint seems to be grounded in one of the methodological pillars of Kelsen's Pure Theory of Law, the

75 Ibid, 229.

76 Herbert Hart, The Concept of Law (With an Introduction by Leslie Green and a Postscript edited by Penelope A. Bulloch and Joseph Raz) (3rd edn, Clarendon Press 2012) 185-186.

77 At yet another place in the Postscript, Hart says that "the existence and content of the law can be identified by reference to the social sources of the law (e.g. legislation, judicial decisions, social customs) without reference to morality except where the law thus identified has itself incorporated moral criteria for the identification of the law." (ibidem, 269) This is what places Hart's theory within the camp of 'inclusive' or 'soft' positivism.

\section{PROBLEMA}


IS LEGAL POSITIVISM TENABLE BEYOND MORAL RELATIVISM?

one drawing a sharp distinction between the worlds of 'is' and 'ought'. In articulating the stance of his positivist account with respect to the relation between legality and morality, Hart presents his defense of the 'separation thesis' 'as part of the history of an idea', which has its memorable roots in Bentham's and Austin's writings. ${ }^{78}$ While the latter famously uttered that ' $[\mathrm{t}] \mathrm{he}$ existence of law is one thing; its merit or demerit is another', 79 the former argued that the crucial methodological distinction has to be made between the investigation of what the law is ('expository jurisprudence') and the investigation whether the existing law ought to be in line with a certain assumed standard ('censorial jurisprudence'). ${ }^{80}$ It follows from this 'simple and glaring' truth (Austin) that any/anyone's standard on what the law ought to be cannot be taken as the criterion for determining what the law is.

It is very well known that, unlike Kelsen, neither Bentham nor Austin was a moral relativist. To the contrary, both authors are well known for advancing the moral philosophy of utilitarianism, which holds that the principle of utility is the ultimate and self-evident moral axiom of right and wrong. ${ }^{81}$ However, neither of them believes that some necessary and morally uncontroversial content of law can be directly inferred from this paramount principle. Bentham, for instance, is hostile to the idea of humans possessing some natural, pre-legal rights, not granted by a positive legal order. Simply put, he is of the opinion that the principle of utility cannot directly generate obligations or duties. As Hart notices, for Bentham, 'a necessary condition of a man having an obligation to act in a certain way is

78 Herbert Hart, 'Positivism and the Separation of Law and Morals' in Essays in Jurisprudence and Philosophy (Clarendon Press 1983) 50.

79 John Austin, The Province of Jurisprudence Determined (Wilfrid E Rumble ed, Cambridge University Press 1995) 157.

80 Jeremy Bentham, An Introduction to the Principles of Morals and Legislation (1781) (Batoche Books 2000) 234.

81 Ibid, 15-16. 


\section{Miodrag JOVANOVIĆ}

the likelihood of suffering in the event of failure so to act'. Since such a suffering is not likely in the case of an obligation directly stemming from the principle of utility, it cannot be on a par with the 'proper' legal obligation. ${ }^{82}$ Moreover, some such directly inferred 'utilitarian entitlements', in the form of pre-legal rights, 'would fluctuate with changing circumstances and have none of the stability over time and consequent availability as guides to action both for the right-holder and others'. ${ }^{83}$ Austin, in a similar fashion, argues that 'no scheme of duties perfectly complete and unambiguous' can be deduced from the utility, even when this principle is understood 'as an index to the Divine will'. ${ }^{84}$

Consequently, both Bentham's and Austin's insistence on the distinction between the law as it is and the law as it ought has nothing to do with a particular meta-ethical stance. In Hart's opinion, what these utilitarians want primarily to emphasize is that there are 'two dangers between which insistence on this distinction will help us to steer'. First of them is 'that law and its authority may be dissolved in man's conceptions of what law ought to be', while the second concerns 'the danger that the existing law may supplant morality as a final test of conduct and so escape criticism.' ${ }^{\prime 25}$ Hart follows in their footsteps, insofar as his endorsement of the 'separation thesis' is primarily driven by similar pragmatic motives. When discussing whether, in classifying what counts as a legal rule, we should exclude an unjust legal rule from the realm of 'law', he says that we are faced with a narrower and a wider concept of classification - 'If we are to make a reasoned choice between these concepts, it must be because one is superior to the other in

82 Herbert LA Hart, 'Natural Rights: Bentham and John Stuart Mill' in Essays on Bentham - Studies in Jurisprudence and Political Theory (Clarendon Press 1982) 86-87.

83 Ibid, 86.

84 Austin (n 79) 159. This is so, because 'the will of God, whether indicated by utility or by a moral sense, is equally matter of dispute'. Ibidem 162 .

85 Hart (n 78) 54. 
Este libro forma parte del acervo de la Biblioteca Jurídica Virtual del Instituto de Investigaciones Jurídicas de la UNAM www.juridicas.unam.mx

IS LEGAL POSITIVISM TENABLE BEYOND MORAL RELATIVISM?

the way in which it will assist our theoretical inquires, or advance and clarify our moral deliberations, or both.' Eventually, he concludes that the narrow conception is neither theoretically superior, because it would lead us to exclude certain rules even though they exhibit all the other complex characteristics of law, 86 nor is preferable from the standpoint of practical morality, because 'it scarcely seems' that this conception 'is likely to lead to a stiffening of resistance to evil'. ${ }^{87}$

As already pointed out, Hart is widely perceived as a moral relativist. ${ }^{88}$ Yet, he generally tends to disburden jurisprudence from heavy, and seemingly pointless, philosophical and theoretical disputes. ${ }^{89}$ According to him, one such dispute in moral philosophy concerns the status and rela-

86 Hart (n 76) 209.

87 Ibid, 210.

88 Surely, with good reasons. For instance, in criticizing Finnis's revival of the natural law doctrine, Hart at one place says that he has other objections to this theory, apart from 'disagreement with its underlying philosophy of self-evident objective values'. Herbert Hart, 'Introduction' in Essays (n 78) 11.

89 For instance, in criticizing general approach to definition of terms, such as 'right', 'duty', or 'corporation', which often result in the birth of distinctive jurisprudential theories, Hart asks: 'can we really not elucidate the meaning of words which every developed legal system handles smoothly and alike without assuming this incubus of theory?' (Herbert Hart, 'Definition and Theory in Jurisprudence', in Essays (n 78) 23). However, as pointed out by Jonathan Cohen, one can hardly 'screen off juristic definition as a relatively uncontroversial topic, from the heated atmosphere of juristic theory'. This is so, because 'any adequate elucidation of legal terms like 'right' or 'corporation' is inevitably bound up - implicitly or explicitly, systematically or piecemeal — with what Hart would call "theory", and that this connection need not involve any linguistic muddle'. Jonathan Cohen, HLA Hart, 'Symposium: Theory and Definition in Jurisprudence' (1955) 29 Proceedings of the Aristotelian Society, Supplementary Volumes 213, 215-16. I tried to prove Cohen's point by demonstrating the inadequacy of Hart's method of 'paraphrasing', supposedly devoid of this 'incubus of theory', in the conceptualization of collective rights. Miodrag A Jovanovi Collective Rights - A Legal Theory (Cambridge University Press 2012) 28-44. 


\section{Miodrag JOVANOvić}

tion of moral principles to the rest of human knowledge and experience'. After acknowledging that there exist two extremes and a number of 'complicated and subtle variants' of moral philosophies, Hart eventually states that in the rest of the treatise he 'shall seek to evade these philosophical difficulties',90 and that 'the question of the objective standing of moral judgments' should be principally 'left open by legal theory'. 91

Nevertheless, in elucidating the issue of the separation of law and morality, Hart considers necessary to dispel the source of confusing the theoretical stance of legal positivism with moral theories of relativism and non-cognitivism. ${ }^{92}$ After the exposition of the key arguments of these and rival meta-ethical positions, Hart advises us to suppose that the rejection of 'noncognitive' theories of morality is warranted. He wonders, then, whether some direct conclusion 'would follow from this as to the nature of the connection between law as it is and law as it ought to be?' His answer is prompt and clear: 'Surely, from this alone, nothing.' This is so, because [1]aws, however morally iniquitous, would still (so far as this point is concerned) be laws. The only difference which the acceptance of this view of the nature of moral judgments would make would be that the moral iniquity of such laws would be something that could be demonstrated ... Proof that the principles by which we evaluate or condemn laws are rationally discoverable, and not mere 'fiats of the will', leaves untouched the fact that there are laws which may have any degree of iniquity or stupidity and still be laws ... Surely something further or more specific must be said if disproof of 'noncognitivism' or kindred theories in

90 Hart (n 76) 168.

91 Ibid, 254.

92 'I think (though I cannot prove) that insistence upon the distinction between law as it is and ought to be has been, under the general head of "positivism", confused with a moral theory according to which statements of what is the case ("statements of fact") belong to a category or type radically different from statements of what ought to be ("value statements").' Hart (n 78) 82. 
IS LEGAL POSITIVISM TENABLE BEYOND MORAL RELATIVISM?

ethics is to be relevant to the distinction between law as it is and law as it ought to be, and to lead to the abandonment at some point or some softening of this distinction. ${ }^{93}$

While rejecting the idea that a separate legal rule or a piece of legislation may be stripped of its quality of legality due to its inconsistence with some moral standard, Hart, at the same time, argues that there may be some further connections, even overlappings, between law and morality, when the focus of our attention is the legal system as a whole. Hart elaborates this point in his teaching on "natural" necessity'. After generally criticizing the old, teleological doctrine of natural law, Hart endorses a modest teleological standpoint, based on 'a mere contingent fact which could be otherwise, that in general men do desire to live'. ${ }^{94}$ From this point, Hart goes on to argue that there are certain general features of human nature and the world in which human beings live, which are so obvious that they constitute 'elementary truths', 'truisms', and 'as long as these hold good, there are certain rules of conduct which any social organization must contain if it is to be viable'. Moreover, these rules may be considered as the justifiable 'minimum content of Natural Law' and they 'constitute a common element in the law and conventional morality'. ${ }^{95}$

As noticed by Hart, the following facts 'afford a reason why, given survival as an aim, law and morals should include a specific content'. ${ }^{96}$ Hence, the free use of violence stems from human vulnerability; restriction on the use of aggression stems from approximate equality; a system of mutual forbearance stems from limited altruism; a minimum form of property stems from limited resources; and finally, some form of sanctions stems from limited understanding and strength of will. ${ }^{97}$ Furthermore, Hart argues

93 Ibid, 84.

94 Ibid (n 76), 192.

95 Ibid, 193.

96 Ibid.

97 Ibid, 194-198. 
Este libro forma parte del acervo de la Biblioteca Jurídica Virtual del Instituto de Investigaciones Jurídicas de la UNAM

\section{Miodrag JOVANOVIĆ}

that every system of general rules has to be administered in line with the standard of 'natural procedural justice', according to which alike cases should be treated alike. Hence, it is safe to conclude that 'there is, in the very notion of law consisting of general rules, something which prevents us from treating it as if morally it is utterly neutral, without any necessary contact with moral principles'. ${ }^{98}$

\section{Contrasting Two Theories in the Positivist Tradition}

Kelsen's defense of the 'separation thesis' should be evaluated against the aforementioned postulates of his theory concerning the subject and methods of jurisprudential study. One of the often raised arguments against the "purification' project states that law cannot be studied outside of its social context, as allegedly assumed by Kelsen. However, as already pointed out, Kelsen openly acknowledges the possibility of sociological jurisprudence. What he, nonetheless, believes is that jurisprudence, as an empirical, and yet, normative science of law, has logical priority over the sociological study of legal phenomena. ${ }^{99}$ Moreover, if positive law, as a normative system, is the subject of study, Kelsen approves of no other method as the genuine legal method than the one employed by the Pure Theory of Law. 100 This does not imply, nevertheless, that history or so-

98 Hart (n 78) 80.

99 Cf. Raz, 'The Purity of the Pure Theory', in The Authority of Law (n 4) 294-295.

100 This is apparently not the case with Hart, who famously utters that his treatise on the concept of law 'may also be regarded as an essay in descriptive sociology'. (Hart (n 76) v). The question whether there is only one correct method in studying law belongs to the earlier mentioned set of open and not often discussed meta-theoretical issues. To be sure, it cannot be seriously addressed here. It is raised to the extent that it is an element of an overall methodological structure of Kelsen's theory, whose other parts will be examined in more detail. 
IS LEGAL POSITIVISM TENABLE BEYOND MORAL RELATIVISM?

ciology of law is less 'scientific' than the Pure Theory of Law. ${ }^{101}$

Concerning the scientific aspiration of jurisprudence, which is the first pillar of Kelsen's methodological approach, Raz considers it 'clearly fallacious'. He says that methods have to be adjusted to the object of study, and, hence, if it "cannot be studied "scientifically" then its study should not strive to be scientific'. ${ }^{102}$ A great deal of ink has been spilt in philosophy of science over the problem of demarcating scientific from pseudo-scientific research. Regardless of whether philosophy of science indeed spectacularly failed in this attempt, as claimed by Leiter, ${ }^{103}$ it suffices for our purposes to notice that Kelsen's main preoccupation is to 'rescue' jurisprudence from theological speculation and metaphysics (which he attributes to the natural law doctrine), 'through the advance of empirical science'. ${ }^{104}$ In doing so, Kelsen is committed to the idea that the explanation of social phenomena, including law, could be conducted using methodological tools similar to those of the natural sciences. ${ }^{105}$ Hence, the 'scientific' aspiration of the

101 'The law may be the object of different sciences; the Pure Theory of Law has never claimed to be the only possible or legitimate science of law. Sociology of law and history of law are others. They, together with the structural analysis of law, are necessary for a complete understanding of the complex phenomenon of law.' Hans Kelsen, 'Law, State and Justice in the Pure Theory of Law' (1948) 57 The Yale Law Journal 377, 383.

102 Raz (n 99) 297.

103 Leiter (n 10) 663.

104 Kelsen, 'Natural Law Theory and Legal Positivism' in General Theory of Law and State (n 54) 433. Raz himself acknowledges that Kelsen was right in assuming that "normative jurisprudence is no less empirical than sociological jurisprudence'. Raz (n 99) 294.

105 Priel believes that, in this respect, Kelsen was much closer to the utilitarian predecessors than Hart. Priel argues that unlike Hobbes, Bentham, Austin, Kelsen and Ross, whose legal positivism was grounded in a particular version of positivism as defined in the philosophy of science, 'around the 1960s jurisprudence and in particular legal positivism have undergone change towards anti-positivism. Central to this trend was the idea that proper jurisprudential inquiry must be conducted from the "internal point of view"', which is the tendency opposed to 'scientism' 


\section{Miodrag JOVANOVIĆ}

Pure Theory of Law has to be viewed primarily as an attempt to provide epistemological grounds for the theory of legal knowledge, and cannot be dismissed as such, on the grounds that it is methodologically counterintuitive or unsound. 106

The remaining pillars of the 'purification' project - methodological dualism and meta-ethical relativism - are intricately intertwined and, hence, are often the subject of compound criticisms. Though there are a number of issues in Kelsen's theory that are targeted in scholarly literature, I will here tackle only two of them, which are potentially most detrimental for the sustainability of the 'separation thesis', as developed within the Pure Theory of Law. Raz offers the first line of criticism, although not directly relating to the aforementioned problem. According to Raz, Kelsen is unable to ground jurisprudence as a normative discipline in his version of moral relativism. In fostering the idea that the division between Sein and Sollen necessitates the respective disciplinary classification, which eventually places jurisprudence within the camp of normative sciences, Kelsen departs from 'the reductive semantic thesis', commonly associated with legal positivism. This thesis states that legal statements are non-normative, descriptive statements of some sort. ${ }^{107}$ This departure leads Kelsen in the next step to adopt 'a cognitivist interpretation of all normative discourse'. Unlike Hart, who is an expressivist, Kelsen advances an understanding of a normative statement which articulates a practical attitude, insofar as it conveys 'a belief in the existence of a valid norm' and, consequently, of a value constituted by the given norm. ${ }^{108}$ Hence, Raz believes that Kelsen 'for the most' part sticks to the cognitivist view, as applicable to both legal and moral normative statements. Such a stance is consistent with value-skepticism, according to which all normative statements are false. And yet, Kelsen is not a skeptic, he is a self-declared moral relativist. 'Unfortunately', concludes Raz, 'Kelsen's version of relativism is the familiar and incoherent one by which relativ- 
IS LEGAL POSITIVISM TENABLE BEYOND MORAL RELATIVISM?

ism is the non-relativist position that each person's value apply only to himself and each society's values to itself'. 106

Kelsen indeed appears at times as advancing this 'crass and vulgar relativism'. ${ }^{107}$ This does not mean, however, that he is not aware of the potential pitfalls of philosophical and moral relativism. Kelsen speaks of two perils. First of them is 'a paradoxical solipsism', that is, 'the assumption that the ego as the subject of knowledge is the only existent reality'. This assumption would lead relativistic stance into 'a self-contradiction', or what Raz calls non-relativist relativism, because 'if the ego is the only existent reality, it must be an absolute reality'. And absolute reality implies the existence of absolute values. The second danger is 'a no less paradoxical pluralism'. On the one hand, 'the world exists only in the knowledge of the subject' and, thus, 'the ego is, so to speak, the center of his own world'. On the other hand, one must concede to the simultaneous existence of many egos. As a consequence, one is driven to a paradoxical conclusion that there are as many worlds as there are knowing subjects'. Kelsen argues that philosophical relativism 'deliberately avoids' both perils. By taking into account, as 'true relativism' does, 'the mutual relation among the various subjects of knowledge, this theory compensates its inability to secure the objective existence of the one and same world for all subjects by the assumption that the individuals, as subjects of knowledge, are equal'. This, in Kelsen's opinion, 'implies that also the various processes of cognition in the minds of the subjects are equal', and, accordingly, 'the further assumption becomes possible that the objects of knowledge, as the results of these individual

106 This view 'seems to suggest the oddity that sincere moral statements of a person about his own conduct are always true'. Consequently, '[n]ormative statements about other people would be on this view true if and only if they accord with those other people's beliefs about themselves. Thus it is true that a racist should behave in a racist way'. Raz (n 99) 302.

107 Stanley L Paulson, 'On the Puzzle Surrounding Hans Kelsen's Basic Norm’ (2000) 13 Ratio Juris 279, 293. 
Este libro forma parte del acervo de la Biblioteca Jurídica Virtual del Instituto de Investigaciones Jurídicas de la UNAM www.juridicas.unam.mx

\section{Miodrag JOVANOVIĆ}

processes, are in conformity with one another, an assumption confirmed by the external behavior of the individuals. '108

Moral and philosophical relativism becomes reconcilable with the scientific aspiration of normative disciplines, including jurisprudence, only if the statements of the latter are understood as conditional propositions. Kelsen's famous doctrine of presupposition and 'basic norm' serves exactly this purpose. Thus, whereas the Pure Theory of Law is restricted by the fact that the validity of a positive legal order is based on Grundnorm, as a non-positive norm, this restriction 'does not abolish the opposition between legal positivism and natural-law doctrine'. This is so, because the basic norm has a merely formal and hypothetical character. 109 This, furthermore, implies that the statements of the science of law, describing positive norms as its object, have to be conditional in nature. 'As a science', says Kelsen, jurisprudence 'cannot state absolutely that individuals or states are obliged or entitled by legal norms to behave in a certain way.' What it only states is 'that under the condition that the basic norm conferring on the fathers of the constitution a law-making authority is presupposed as valid, are individuals obliged or entitled, by legal norms based on the constitution, to behave in a certain way.' Jurisprudence, as a science of law, cannot itself presuppose that the aforesaid basic norm is valid, nor can it decide that any non-positive norm is valid, simply because this is beyond the sphere of a science the object of which is this positive legal order'. ${ }^{110}$

Finally, it is worth reminding that the scientific nature of jurisprudence is warranted due to the possibility of verifica-

108 Hans Kelsen, 'Absolutism and Relativism in Philosophy and Politics' (1948) 42 The American Political Science Review 906, 907-908.

109 This is in stark contrast "with the substantive norms of natural law prescribing a definite human behavior as in conformity with nature (and that means as just) and prohibiting a definite human behavior as contrary to nature (and that means as unjust)'. Hans Kelsen, 'Science and Politics' (1951) 45 The American Political Science Review 641, 650.

110 Ibid. 
tion of the existence, that is, validity of a legal norm. Validity of a norm is not only grounded in the presupposed validity of a basic norm, but is also conditional upon certain empirical facts. First of them is some law creating fact (eg a legislative, judicial, or administrative act), by which a given norm came into existence; second of them concerns by and large effectiveness of the legal order as a whole. Insofar as a legal norm constitutes a value, any statement to the effect that certain behavior is or is not in conformity with that norm is a value judgment. However, this specific value of legality or illegality 'is not opposed to reality', and, accordingly, any such value judgment of jurisprudence is 'a special kind of judgment about reality', which 'is verifiable by experience'. ${ }^{111}$

Not so, however, with moral norms, that is, norms of justice, to which no reality corresponds, which eventually renders 'judgments of justice' as moral judgments objectively unverifiable. Thus, one may claim, contra Raz, that what Kelsen for the most part endorses is non-cognitivism with respect to moral normative statements. ${ }^{112}$ Hence, Raz's line

111 Kelsen says that 'the object of legal science may be characterized as legal reality. The difference between natural reality and legal reality is that legal reality as described by legal science consists of facts which have under the condition that the validity of the basic, non-positive, norm is presupposed - specific meaning: the meaning of positive norms'. Ibid, 651.

112 Inconclusiveness as to whether Kelsen is a moral cognitivist or non-cognitivist directly stems from a particular incoherence within his theory. Raz would have been justified in advancing his claim if Kelsen had managed to demonstrate that moral norms could be scientifically studied, that is, if there existed some 'moral reality' comparable to the aforementioned 'legal reality'. For start, Kelsen speaks of a positive moral order. The only difference between a positive legal order and a positive moral order concerns 'how they command or prohibit a certain behavior'. Whereas the former is coercive, the latter is not. (Kelsen (n 39) 62). Furthermore, just as in case of legal norms, moral norms are also created by acts of individuals: "The norms of a positive moral order may be established by the sermons or writings of a religious founder or by custom, that is, by the habitual behavior of the members of a social community.' Finally, Kelsen indeed mentions ethics as a normative science, whose task is cognition and 
Este libro forma parte del acervo de la Biblioteca Jurídica Virtual del Instituto de Investigaciones Jurídicas de la UNAM www.juridicas.unam.mx

\section{Miodrag JOVANOVIĆ}

of criticism is unable to endanger Kelsen's moral relativism, which stands in the background of the establishment of the 'separation thesis'.

The second criticism comes from Beyleveld and Brownsword. They argue that Kelsen's doctrine of presupposition and basic norm precludes him from developing a theory of legal positivism. This is so, because the Pure Theory of Law is in violation of the 'separation thesis', insofar as 'the basic norm sets a material moral test for legal validity and ... failure to conform with the moral condition is fatal to legality'. ${ }^{113}$ Kelsen endorses the stance of moral relativism, and though his theory cannot be, for that reason, characterized as a full-fledged natural law theory ('Objectivistic Legal Idealism'), it, nonetheless, falls under the rubric of 'Relativized

description of positive moral norms constituting value. (Kelsen (n 113) 648). This may all seem to work in favor of Raz's argument. However, on a closer look, it transpires that Kelsen failed in developing a coherent cognitivist moral account, if this was his intention in the first place. In comparing law and morals as normative orders, Kelsen also acknowledges that ' $\mathrm{t}]$ he difference between a positive and a non-positive norm is particularly clear in the field of law' (ibid 649), which implies that this distinction is less noticeable in the field of morals. This is so, because, there is no 'unique standard of justice', while there is 'only one positive law' (Kelsen (n 65) 229). Moreover, since moral order is not coercive, and there are no separate institutions for its administration, it is far less clear what would constitute a by and large effective positive moral order. The same sort of uncertainty may be connected with the moral creating acts, because the vast majority of moral norms stem from an unwritten source, such as custom. Without the conclusive existence of these two sorts of facts, there exists no moral reality, comparable to that of legal reality and, consequently, ethics can hardly be established as the science of positive moral norms. Kelsen seems to be aware of these problems, but he thinks that they can be alleviated by drawing similarities between positive moral orders and primitive legal orders, which are likewise wholy decentralised'. Hans Kelsen, 'Law and Morality', in Hans Kelsen, Essays in Legal and Moral Philosophy (selected and introduced by Ota Weinberger) (Petar Heath tr, D Reidel 1973) 86. Yet, I do not think that these similarities, even if existent, are strong enough to warrant the establishment of ethics as a normative discipline on Kelsenian terms.

113 Beyleveld and Brownsword (n 55) 114. 
IS LEGAL POSITIVISM TENABLE BEYOND MORAL RELATIVISM?

Legal Idealism'. Beyleveld and Brownsword believe that Kelsen's interpretation of an 'ought' as an objective meaning of an act of will114 entails treating "the "ought" as an "ought" of a moral discourse, as an "ought" that expresses a moral obligation, moral permission, etc'.115 They justify this strong claim not only by noticing that, for Kelsen, 'legal norms have moral meaning', 116 but by also emphasizing few words from a passage, which discusses the case of a man in need who asks another man for help. Kelsen says that the subjective meaning of this request is that the other ought to help him'. However, 'in an objective sense he ought to help (that is to say, [Beyleveld's and Brownsword's emphasis] he is morally obliged to help) only if general (that is, 'higher') norm - established, for instance, by the founder of a religion - is valid that commands, "Love your neighbor"'. This latter norm is, furthermore, valid only under the presupposition that one ought to behave as the religious founder has commanded. This presupposed norm, 'establishing the objective validity of the norms of a moral or legal order', is Grundnorm of a moral or a legal order.117 For Beyleveld and Brownsword, this comment, and particularly the emphasized phrase, is the crucial evidence that the

114 They refer to the following long passage from Kelsen's Pure Theory of Law (7-8): "If the "ought" is also the objective meaning of the act, the behavior at which the act is directed is regarded as something that ought to be not only from the point of view of the individual who has performed the act, but also from the point of view of the individual at whose behavior the act is directed, and of a third individual not involved in the relation between the two. That the "ought" is the objective meaning of the act manifests itself in the fact that it is supposed to exist (that the "ought" is valid) even if the will ceases to exist whose subjective meaning it is - if we assume that an individual ought to behave in a certain way even if he does not know of the act whose meaning is that he ought to behave in this way. Then the "ought", as the objective meaning of an act, is a valid norm binding upon the addressee, that is, the individual at whom it is directed.'

115 Beyleveld and Brownsword (n 55) 119.

116 Ibid. They particularly refer to the pages 65-67 of Kelsen's Pure Theory of Law.

117 Ibid. This example is discussed in Pure Theory of Law, 8. 


\section{Miodrag JOVANOVIĆ}

basic norm of a legal order not only has a moral meaning, but is a moral condition of legal validity.

It seems to me that this conclusion only adds to the confusion often surrounding Kelsen's view on the nature of and relation between law and morality. For instance, the pages that Beyleveld and Brownsword refer to, when charging Kelsen for holding that 'legal norms have moral meaning', are placed under the headings 'Relativity of Moral Value' and 'Separation of Legal and Moral Orders'. In these paragraphs, however, Kelsen tries to unravel the meaning of phrases, such as 'law is moral by nature' and 'law in its essence represents a moral minimum'. As for the first of them, Kelsen says that "the law constitutes a value precisely by the fact that it is a norm: it constitutes the legal value which, at the same time, is a (relative) moral value; which merely means that the law is norm."118 As for the second phrase, Kelsen notices that it cannot be accepted within the Pure Theory of Law, because it presupposes absolute morality and such a standard of morality cannot be established by scientific cognition. This does not imply that such a standard cannot be employed in the evaluation of a legal order. In fact, every moral system can serve this purpose. However, one must be aware, in assessing the morality or justness of the given positive legal order, "that the standard of evaluation is relative and ... that a legal order evaluated on the basis of one moral system as unjust may well be evaluated as just on the basis of another moral system.'119

Therefore, what these passages demonstrate is primarily that Kelsen does not deny, nor overlook certain important, some would say necessary, connections between law and morality, ${ }^{120}$ which stem from the mere fact that they are

118 Kelsen (n 39), 65.

119 Ibid, 67.

120 It is interesting to draw a parallel here with Green's more recent argument that law is both 'justice-apt' and 'morally fallible'. Green says that 
IS LEGAL POSITIVISM TENABLE BEYOND MORAL RELATIVISM?

both normative systems, which in the last instance means that they constitute values. ${ }^{121}$ By elucidating the nature of these connections, Kelsen, furthermore, acknowledges that moral norms can be used for the evaluation and criticism of legal norms. ${ }^{122}$ However, all this does not imply that 'an objective "ought" has the meaning of a moral obligation'.123 The idea of an 'ought' (Sollen) has in Kelsen's theory epistemological function of the Kantian relative a priori. Moreover, the concept of 'ought' is for Kelsen a general and an 'umbrella' concept (Sammelbegriff), 'which simply embrace all deontic modalities'. ${ }^{24}$ Through the concept of 'objective "ought"' Kelsen tries to draw the line between a norm, that is, Sollen, and a norm-creating act, that is, Sein. ${ }^{125}$ Since normative sciences, including jurisprudence, study norms, the only object of their research can be those norms ('oughts') which have the objective meaning, that is, which are valid norms. And only insofar as an objective 'ought' is the subject of a normative science, can the given normative science claim that its statements are correct or

'[1]aw is the kind of thing that is apt for inspection and appraisal in light of justice', but 'that there is no guarantee that law will satisfy those moral standards by which law should be judged'. Leslie Green, 'Positivism and the Inseparability of Law and Morals' (2008) 83 New York University Law Review 1035, 1050, 1056.

121 'If, presupposing only relative values, the demand is made to separate law and morals in general, and law and justice in particular, then this demand does not mean that law and morals, law and justice, are unrelated.' Kelsen (n 39) 66.

122 Hence, Hart was fatally flawed in charging Kelsen for allegedly excluding the possibility of a moral criticism of law. Hart (n 51) 723.

123 Beyleveld and Brownsword (n 57) 119.

124 Robert Alexy, 'Hans Kelsens Begriff des Relativen Apriori' in Alexy and others (eds), Neukantianismus und Rechtsphilosophie (n 46) 186.

125 "Ought" is the subjective meaning of every act of will directed at the behavior of another. But not every such act has also objectively this meaning: and only if the act of will has also the objective meaning of an "ought", is this "ought" called a "norm".' Kelsen (n 39) 7. 
Este libro forma parte del acervo de la Biblioteca Jurídica Virtual del Instituto de Investigaciones Jurídicas de la UNAM www.juridicas.unam.mx

\section{Miodrag JOVANOVIĆ}

true. ${ }^{126}$ Validity of a norm and, hence, its status of an objective 'ought' is ultimately grounded in the presupposed Grundnorm and conditioned upon the by and large effectiveness of the normative order. Only under these conditions can one differentiate between a mere request of a man in need of help and a morally valid obligation to help one in need (this, and only this, was morale of the aforementioned Kelsen's example), as well as between a mere command of a gangster and a legally valid obligation. ${ }^{127}$ Since each normative system has its own material sphere of validity, ${ }^{128}$ Kelsen certainly does not invoke the idea that the basic norm of a legal order sets the moral test for legal validity, as claimed by Beyleveld and Brownsword. This, eventually, implies that the doctrine of presupposition is not per se an obstacle

126 Alexy (n 128) 199. For the reasons explicated earlier, I have doubts that ethics can be coherently constituted as a normative science within Kelsen's methodological postulates.

127 The gunman story precedes the one of a man in need of help, and this furthermore demonstrates that what Kelsen wanted was merely to underline the difference between a norm-creating act and a norm, using the examples related to both law and morality.

128 'How they [men] shall behave, what acts they shall do or forbear from doing, that is the material sphere of the validity of a norm. Norms regulating the religious life of men refer to another material sphere than norm regulating their economic life.' The same applies to law and morality. (Kelsen (n 54) 42). This passage is important for Hart's comments of Kelsen's denial of 'the simultaneous validity of two norms which contradict one another', such as in the case of a valid legal norm requesting one behavior, and a valid moral norm requesting the opposite behavior (Kelsen (n 54) 375). Hart realizes that Kelsen's statement that 'the jurist ignores morality as a system of valid norms, just as the moralist ignores positive law as such a system' can be construed to mean simply that neither of them should operate outside the scope of his disciplinary task. However, from this alone does not follow that statements about conflicts between law and morality 'cannot be made both meaningfully and truthfully'. According to Hart, 'Kelsen denies this when he adds, "And there is no third point of view".' (Hart (n 51) 726). To my mind, this Hart's criticism fairly demonstrates the distinction between his 'expressivist' and Kelsen's 'cognitivist' view of legal norms, as well as Hart's insistence on the 'internal point of view' which differs from Kelsen's external, 'scientific' approach to the subject matter. 
IS LEGAL POSITIVISM TENABLE BEYOND MORAL RELATIVISM?

for a sustainable defense of the 'separation thesis' and, hence, of legal positivism. Something further has to be said about this doctrine if Kelsen's attempt to establish a theory in the positivist tradition is to be assessed as failure. And indeed, there are a number of potentially more destructive criticisms of this doctrine. ${ }^{129}$ And yet, even if some or all of them are plausible, Kelsen's defense of the 'separation thesis' would still largely depend on his meta-ethical stance of moral relativism. ${ }^{130}$

This seems not to be the case with Hart. He believes that the defense of the 'separation thesis' is unrelated to a particular meta-ethical stance and that it is, furthermore, compatible with his teaching on the 'natural necessity'. At one point, Hart says that his argument in favor of 'the minimum content of natural law' 'should not satisfy anyone who is really disturbed by the Utilitarian or "positivist" insistence that law and morality are distinct'. ${ }^{131}$ However, it would be interesting to reverse the question and ask whether Hart himself, as a self-declared legal positivist, should be disturbed with his teaching on 'natural necessity' as a potential violation of the 'separation thesis'. I suspect that there are good reasons for such a worry. Although Hart at times hesitates to determine whether the established "necessity' is 'logical (part of the "meaning" of law) or merely

129 Cf. Alexy's investigation how relative is Kelsen's relative a priori (Alexy (n 128) 200); Paulson's critique of Kelsen's 'regressive version of the transcendental argument' (Paulson (n 111) 288ff); Bulygin's critique of Kelsen's conception of validity qua binding force (Eugenio Bulygin, 'An Antinomy in Kelsen's Pure Theory of Law', in Paulson and Litschewski Paulson (eds) (n 38) 297-315); Raz's charge that Kelsen tends to confuse "statements conditional on the validity of the basic norm" and the so-called "detached statements"'. Raz (n 99) 306.

130 To be sure, I cannot dwell here on all the plausible options for the reconstruction of Kelsen's theory, if all or some of the aforementioned criticisms against it were warranted.

131 Hart (n 78) 81. 
Este libro forma parte del acervo de la Biblioteca Jurídica Virtual del Instituto de Investigaciones Jurídicas de la UNAM www.juridicas.unam.mx

\section{Miodrag JOVANOVIĆ}

factual or causal',132 it seems that he is advancing an important theoretical claim about the object of his study. ${ }^{133}$ Namely, not only these 'simple truisms', in his opinion, 'disclose the core of good sense in the doctrine of Natural Law', but they also 'explain why the definition of the basic forms of (law and morals) in purely formal terms, without reference to any specific content or social needs, has proved so inadequate'. Furthermore, it is in this form, says Hart, that 'we should reply to the positivist thesis' - or, more precisely, Kelsen's thesis - 'that "law may have any content"'. ${ }^{134}$ Finally, Hart is perfectly clear when stating that without the aforementioned necessary rules, 'there would be no point in having any other rules at all', 135 and that their 'omission ... from the legal system could not be excused on the ground that the existence of a social morality made them unnecessary'. 136

132 He says that this issue 'can safely be left as an innocent pastime for philosophers'. (ibid 79). At some other place, however, Hart explicitly says that the connection between natural facts and the content of law and morality is not of the causal kind. Hart (n 76) 194.

133 In dispelling the myth that legal positivism has to deny the existence of any necessary connection between law and morality, Raz provides several examples of such connection. One of them is Hart's teaching. Even though Raz argues that the 'natural necessity' is not equivalent to 'conceptual, a priori necessities', he, nonetheless, notices that 'natural necessities ... are sufficiently secure to merit the attention of the theory of law, assuming that they are not trivial in nature'. Joseph Raz, 'About Morality and the Nature of Law' in Between Authority and Interpretation - On the Theory of Law and Practical Reason (OUP 2009) 168-169. Raz obviously holds that Hart's 'natural necessity' is not trivial. Similarly, Postema observes that 'Hart explored relations between law and morality which, while never conceptually necessary, nevertheless were to compelling enough for him to acknowledge a "naturally necessary" minimum moral content of law, but he took pains to emphasize the minimal character of this link.' Gerald J. Postema, Legal Philosophy in the Twentieth Century: The Common Law World (A Treatise of Legal Philosophy and General Jurisprudence, Volume 11) (Springer 2011), 547.

134 Hart (n 76) 199.

135 Hart (n 78) 80.

136 Hart, 'Problems of the Philosophy of Law' in Essays (n 78) 114. 
Consequently, the viability of a legal system - taken here to mean its very existence - is conditional upon the adoption of the specific moral content, however minimal it is. Moreover, not only is Hart's 'minimum content' controversial, ${ }^{137}$ but it is defined through the process of jurisprudential prescription of what law ought to be - 'given survival as an aim, law and morals should include a specific content'. ${ }^{138}$ Put briefly - the 'is' of law depends on the minimum 'ought'-to-be-law. And once the starting assumption - that no 'ought' can be inferred from 'is' and vice versa is abolished, there is no principal reason why jurisprudence should firmly stick to it in, say, its inquiry of legal validity of morally iniquitous laws. A plausible way out would be to state that the 'separation thesis' stands in any way, because one cannot furnish an objective and absolute standard of what counts as a morally iniquitous law. ${ }^{139}$ But, as

137 In devising his teaching on 'natural necessity', Hart primarily relies on Hobbes's and Hume's conceptions of human nature (Hart (n 78) Notes to the Chapter IX, 303), and he tends to provide an 'empirical version' of the natural law theory (Hart (n 140) 113). However, it is interesting to compare his findings with those of a field anthropologist, such as Margaret Mead. In the same year of the publication of The Concept of Law, she published an article in which she tried to determine, based on the comprehensive comparative fieldwork, some common legal rules for all human societies, which she considered the minimal core of 'natural law'. Her list of those rules is different and less extensive than Hart's. Margaret Mead, 'Some Anthropological Considerations Concerning Natural Law' (1961) 6 Natural Law Forum 51, 52-53.

138 Hart (n 76) 193. One may infer from Hart's using of 'should' in the aforementioned sentence that he has still not taken a step in the direction of moral realism. However, taking into account all the other statements in this section of the book, the contrary reading seems to be more warranted. In fact, at the very same page of the book, reader can find Hart's claim that 'there are certain rules of conduct which any social organization must contain if it is to be viable.' (emphasis mine) As already indicated, for Hart, viability stands for the existence of a legal system, insofar as without this minimum content no other rules would make sense.

139 Bulygin, for instance, argues, and with good reasons, that Kelsen was unable to preserve this 'theory of two worlds' within his 'purification' project, insofar as validity of a legal norm is conditional upon several 


\section{Miodrag JOVANOVIĆ}

we saw, Hart believes that the 'separation thesis' of legal positivism is in no way dependent upon the meta-ethical stance of moral relativism, and that it would be equally sustainable even if instances of immoral laws could be established as verifiable facts. In that respect, he radically differs from Radbruch who, even before his Post-War 'conversion'140 from legal positivism and full-fledged moral relativism, argued that the natural law theory would be correct if we could establish instances of just (moral) law by means of the exact science, because "no justification can be conceived of verifiably false law'. ${ }^{141}$ What this thesis conveys is that if there were moral facts of any sort connected to the existence and content of law, and they were discernable, legal theory would have to incorporate these data in its study of law. ${ }^{142}$ This is so, on the account that every theory has to engage in the business of sorting out data that it focuses on, in a way consistent with general epistemic virtues, such as coherency, clarity, comprehensiveness. ${ }^{143}$ Simply put, re-

facts: an act of norm-creation; an act of norm-cancellation or derogation; and efficacy. (Bulygin (n 133) 302-303). Kelsen's way out is exactly the meta-ethical stance of moral relativism.

140 It is Hart who speaks of Radbruch's 'conversion'. Hart (n 78) 72, 73.

${ }_{141}$ Gustav Radbruch, Rechtsphilosophie (7th edn, KF Koehler Verlag 1970) 178-79. In the first edition of his Legal Philosophy, published in 1932, Radbruch shared Kelsen's opinion that this result was not scientifically achievable.

142 Even Waldron, who most forcefully advances the 'irrelevance thesis', seems to suggest that if moral facts were methodologically verifiable in the same sense as scientific facts, than moral objectivism would have probably make difference 'in the way of dispelling arbitrariness' of adjudication. (Waldron (n 32) 179). A more general problem with Waldron's case is that it 'seems indistinguishable from an attack upon objectivism, because it focuses on a purported defect in objectivism - namely, the putative absence of reliable ways of identifying objective moral truths'. (Dale Smith, 'The Use of Meta-Ethics in Adjudication' (2003) 23 OJLS 25, 39). Accordingly, one cannot escape the feeling that Waldron 'defends both anti-objectivism and irrelevance'. Tasioulas (n 30) 212, fn 2.

143 These are, according to Dickson, 'purely meta-theoretical values'. Dickson (n 21) 32. 
IS LEGAL POSITIVISM TENABLE BEYOND MORAL RELATIVISM?

fusing to incorporate relevant and verifiable facts into a theory would imply obfuscating, instead of clarifying the object of study, and would consequently lead to an incoherent and incomprehensive theory.

Hart was certainly aware of this. For instance, in discussing Bentham's resistance to the concept of natural, non-legal rights, Hart notices that "[a] more difficult, but more important question" is why Bentham "was not ready to accept a simple utilitarian theory of non-legal rights as something consistent with his adoption of an unqualified utilitarianism according to which it is "the happiness of the greatest number that is the measure of right and wrong." In Hart's opinion, this moral theory "might seem to supply a criterion for identifying what rights men have in addition to those created by law or arising from social conventions." Since Bentham differentiates between two sorts of legal rights, which Hart labels as "liberty-rights" and "rights to services", it is puzzling "why should Bentham not have said that men have non-legal rights of these same two sorts based on the principle of utility." 144 As already noticed, Hart eventually finds out as "the most important reason for rejecting such a direct utilitarian theory of rights" the fact "that it would have broken the connection between the concept of rights ... and coercive obligations" in Bentham's theory. ${ }^{145}$ However, from this fact alone does not follow that if Bentham's conception of coercive obligation were different, 146 his theory would have not committed him to devise

144 Hart (n. 82) 85.

145 Ibidem, 86.

146 At some other place, Hart provides a more detailed criticism of Bentham's "mixed theory of legal obligation", which contains a mixture of imperative and probabilistic elements. According to Hart, it is opened to the following simple objection: "[T]he statement that a person has a legal obligation to do a particular action can be combined without contradiction or absurdity with the statement that it is not likely that in the case of disobedience he would suffer by incurring some sanction." (Hart, "Legal Duty and Obligation", in Essays on Bentham, 135) Hart subjects Bentham's theory to a further criticism, whose target is the imperative el- 
Este libro forma parte del acervo de la Biblioteca Jurídica Virtual del Instituto de Investigaciones Jurídicas de la UNAM www.juridicas.unam.mx

\section{Miodrag JOVANOVIĆ}

such a direct utilitarian conception of natural rights. It is exactly theoretical consistency and clarity that would have required from Bentham to take such a step. ${ }^{147}$

Accordingly, if Hart were to refute Radbruch and defend his own stance on this issue as coherent, clear and comprehensive, he would have to provide persuasive argumentation why some putative knowledge of verifiably unjust instances of law - provided that particular version of moral objectivism were indeed warranted - has to be excluded from the jurisprudential conceptualization of law and legal validity, whereas, at the same time, some other insights into the nature of connection between legality and morality have to be incorporated in the exposition of essential features of the concept of law. Such a privileged status in Hart's theory, for instance, enjoys Fuller's insight into the 'inner morality of law', for which Hart explicitly says: '[I]f this is what the necessary connection of law and morality means, we may accept it'. ${ }^{148}$ Gardner has recently made an

ement of the theory as well. Ibid., 143-147. Finally, he criticizes the idea, inherited by both Dworkin and Raz, that that 'obligation' and 'duty' have the same meaning in legal and moral contexts. Ibidem, 147-161.

147 In fact, Hart appears to believe that Bentham's utilitarian theory, even without any modifications, commits him to develop a theory of natural, non-legal rights. In an 1988 interview, which was recently published for the first time in English, Hart mentions this as one of the major failures of Bentham's theory: "I myself think that there are many objections to such a utilitarian theory, but it is amazing that a thinker of Bentham's stature should have condemned the whole idea of a non-legal right as useless if not nonsensical without carefully considering the possibilities of such a utilitarian theory." HLA Hart, 'Answers to Eight Questions', in Luís Duarte D'Almeida, James Edwards and Andrea Dolcetti (eds.), Reading HLA Hart's The Concept of Law (Oxford and Portland, Hart Publishing, 2013), 292.

148 Hart (n 76) 207. At some other place, Hart says that some of Fuller's points are valuable, insofar as they are helpful in providing 'a corrective to the view that there is a sharp separation between "ends" and "means" and that in debating "ends" we can only work on each other non-rationally, and that rational argument is reserved for discussion of "means".' (Hart (n 78) 86). This is, again, in stark contrast with Kelsen's thesis that 'judg- 
even stronger claim that in his fable in chapter V Hart appears to favour something like the Fullerian view', according to which no legal system can exist without satisfying some of the demands of the rule of law value, such as certainty or finality. ${ }^{149}$ And yet, in doing so, Hart was trying to demonstrate 'that taking this view is compatible with holding that there are (or at any rate need be) no moral (or otherwise evaluative) criteria of legal validity.'150

However, it transpires that the sustainability of the 'separation thesis' in Hart's theory is substantially weakened once he starts to move towards some 'thin' version of moral realism, ${ }^{151}$ by introducing a limited number of natural facts which constitute reasons for a specific content of both law

ments about ultimate ends or supreme values are, in spite of their claim to an objective validity, highly subjective'. Kelsen (n 113) 645-46.

149 John Gardner, 'Why Law Might Emerge: Hart's Problematic Fable' in D’Almeida, et. al. (n 150), 87.

150 Ibidem 93 (footnote omitted from the original text).

151 Even though there are authors who reject the possibility of justifying some middle-ground position between the two stances, arguing that 'the very idea of a moderate meta-ethical relativism seems to be arbitrary' (Torben Spaak, 'Meta-Ethics and Legal Theory: The Case of Gustav Radbruch' (2009) 28 Law and Philosophy 261, 286), a number of contemporary works in this field advance 'mixed positions' and their central thesis is 'that neither relativism nor objectivism is wholly correct'. (See in general Chris Gowans, 'Moral Relativism', in Edward N Zalta (ed), The Stanford Encyclopedia of Philosophy (2008) http:/ / plato.stanford.edu/en tries/moral-relativism/ accessed 5 February 2013). In that respect, Hart's general ideas are on the same track with some of the recent expositions of the subject matter. One such study is David Wong's Natural Moralities, in which the central idea is that there are certain natural facts about us as human beings that represent universal constraints on how we ought to behave, even though these facts are not constraining enough to yield one true morality. These universal constraints are sufficiently open-ended that they can be in more than one way respected. Accordingly, there can be more than one true morality, and this is what Wong qualifies as the stance of 'pluralistic relativism'. David B Wong, Natural Moralities - A Defense of Pluralistic Relativism (OUP 2006). 
Este libro forma parte del acervo de la Biblioteca Jurídica Virtual del Instituto de Investigaciones Jurídicas de la UNAM www.juridicas.unam.mx

\section{Miodrag JOVANOvić}

and morality. ${ }^{152}$ This is so, due to Hart's firm belief that the 'separation thesis' can be adequately safeguarded with the sole reliance on the pragmatically motivated distinction between law as it is and law as it ought to be. ${ }^{153}$ However, this distinction alone is barely a trump card against the natural law theory, which was the target of criticism of both Bentham and Austin, as well as of Hart. ${ }^{154}$ As pointed out by Boyle, 'natural law' has commonly been understood, both by proponents and adversaries of the natural law theory 'as referring to a set of universal prescriptions whose prescriptive force is a function of the rationality which all human beings share in virtue of their common humanity.' Natural law principles and norms, 'as natural, are addressed to all human beings, and they are held to be accessible to all who are capable of forming the concepts which comprise them'. These fundamental natural law prescriptions are taken to exist, 'and indeed to be truths of a

152 Hart keeps reiterating that these features of the human nature are 'contingent' and that they 'could be otherwise' (Hart (n 76) 192), but if the entire history of humankind testifies to their existence, as Hart obviously believes it does, then they certainly constitute essential features of our concept of 'human'. This, in turn, implies that if they are reasons for a particular content of law, as Hart argues, then this minimum content constitutes an essential feature of the very concept of law.

153 Let us not forget that one of the reasons for Hart's endorsement of the 'separation thesis' lies in the belief that the rival conception of legal validity is not likely 'to lead to a stiffening of resistance to evil'. This theoretical motive is particularly interesting, having in mind that Hart viewed himself as doing descriptive sociology, capturing what our social practices, linguistic and legal, tell us about law. Yet, this is plainly a normative argument in favor of a narrower conception of law and legal validity. I would like to thank Ken Himma for drawing my attention to this potentially problematic aspect of Hart's theory.

154 It is worth reminding that Hart's discussion on laws and morals proceeds from the assertion that the natural law doctrine 'contains certain elementary truths of importance for understanding both morality and law.' However, these are, in Hart's words, to be 'disentangled from their metaphysical setting' and restated 'in simpler terms.' Hart (n 76) 188. 
IS LEGAL POSITIVISM TENABLE BEYOND MORAL RELATIVISM?

kind'. ${ }^{155}$ Thus, according to this doctrine, '[n]ature is conceived of as a legislator, the supreme legislator', ${ }^{156}$ and the set of its fundamental norms and principles co-exist with and, according to the traditional wisdom, take precedence over that of the human legislator, in case these two systems of rules come to conflict. ${ }^{157}$ Since the argument of a natural law theorist is not merely that principles and norms of natural law ought to supplant some norms of positive law, but that they do supplant in cases of conflict, he can easily assent to the distinction between 'law as it is' and 'law as it ought to be'. He can do so without contradicting his principal natural law position, because this distinction demarcates the respective areas of study of legal dogmatics and legal politics. Whereas the former discipline is focused on the analysis of valid law, law as it is (de lege lata), the latter studies law as it ought to be (de lege ferenda). Hence, one can coherently advocate natural law doctrine and subscribe to this disciplinary division. ${ }^{158}$

155 Joseph Boyle, 'Natural Law and the Ethics of Tradition' in George (ed), Natural Law Theory (n 32) 4.

156 Hans Kelsen, "The Natural Law Doctrine Before the Tribunal of Science' (1949) 2 The Western Political Quarterly 481.

157 Finnis argues that the precedence of natural law over positive law, which would imply invalidity of unjust legal rules, is not part of the traditional natural law doctrine and that it came with an erroneous interpretation of the maxim 'Lex iniusta non est lex'. (John Finnis, Natural Law and Natural Rights (2nd edn, OUP 2011) 363-66). Alexy, thus, classifies Finnis's view under the rubric of 'super-inclusive non-positivism'. (Alexy (n 1) 6). However, Shapiro rightly points out that while this 'weak' reading of the natural law thesis is 'not uninteresting', it 'is not so interesting that the dispute over it should constitute the major debate in analytical jurisprudence'. In contrast, 'the debate whether the law ultimately rests on moral facts', which is the traditional wisdom of natural law theory, 'is capable of playing such a role'. Shapiro (n 18) 408, fn 28.

158 This is so, because the natural law thesis normally rests on the assumption that there exist a certain limited number of fundamental legal rules stemming directly from the nature (of God, human, things). With respect to the large majority of legal rules, they are considered to be of con- 


\section{Miodrag JOVANOVIĆ}

Hart seems to disregard this simple insight, which Kelsen was fully aware of. 159 The reason for this might be found in the fact that Hart uncritically traces the footsteps of the utilitarians. Even Bentham's famous distinction between 'two characters' that can say something on the subject of law, which was subsequently endorsed by Austin, refers primarily to the roles of a legal analyst and a legal politician (ie legislator). Whereas '[t]o the Expositor it belongs to shew what the Legislator and his underworkman the Judge have done already: to the Censor it belongs to suggest what the Legislator ought to do in future'. ${ }^{160}$ Hence, censorial jurisprudence is best understood as "the art of legislation."161 Had Hart acknowledged limitations of the de lege lata - de lege ferenda distinction in refuting the natural law doctrine, he might have accepted also that defending the 'separation thesis', as the core thesis of legal positivism, required a more elaborate stance with respect to the jurisprudential status of some putative objective value judgments pertaining to law, provided that such judgments were indeed possible. In that respect, Kelsen's straightforward argument from moral relativism seems to provide far more clear and coherent defense of the 'separation thesis' than Hart's.

\section{CONCLUSION}

The goal of this paper was not to argue that Kelsen's Pure Theory of Law is a sustainable legal theory, and even less so that it is overall a more accurate theoretical exposition of

ventional nature, and, hence, their content can be criticized from a particular policy viewpoint.

159 Kelsen explicitly states that the Pure Theory of Law 'attempts to answer the question what and how the law is, not how it ought to be'. As such, '[i]t is a science of law (jurisprudence), not legal politics'. Kelsen (n 39) 1 .

160 Jeremy Bentham, A Fragment on Government (with an introduction by FC Montague) (Clarendon Press 1891) 99.

161 Bentham (n 80), 234 
IS LEGAL POSITIVISM TENABLE BEYOND MORAL RELATIVISM?

law than Hart's one. Furthermore, this paper was not aimed at defending the meta-ethical stance of moral relativism. Any of these conclusions would quite obviously require separate and more thorough investigations. The main objective of this paper was to investigate whether the argument from moral relativism is central for grounding a tenable positivist theory of law, provided that the 'separation thesis', as defined by Marmor, is the core thesis of legal positivism and that the 'labeling' of a theoretical stance does matter. The 'tenability' of a theory in the positivist tradition was, thus, assessed primarily against this standard, apparently endorsed by all self-identified legal positivists.

What the undertaken analysis demonstrates is that Hart's endorsement of a 'thin' version of moral realism, reflected in his teaching on the 'minimum content of natural law', is detrimental for the sustainability of the 'separation thesis'. This finding, further, leads to the conclusion that moral relativism, as espoused by Kelsen, is indeed in some important respects central for the grounding of a tenable theory in the positivist tradition. From this one may, finally, infer that all those theories that even more openly incorporate Alexy's 'existence thesis' would have even fewer chances to pass the aforementioned threshold of 'tenability' as positivist theories of law. If the preceding analysis was correct, as I believe it was, an alternative approach to the subject matter would imply no less than restating the terms of the traditional jurisprudential debate as to argue that classifying theories of law under different labels does not matter at all and/or that the 'separation thesis' is not definitional of a theory in the positivist tradition. ${ }^{162}$

\section{BIBLIOGRAPHY}

162 As already noticed, both of these claims have been recently advanced by Coleman, but I expressed doubts about his restatement of the 'separability thesis' (as he prefers to call it), which was the starting premise of his argumentation. See n 9. This, certainly, does not mean that both claims could not be defended on some other grounds. 


\section{Miodrag JOVANOVIĆ}

Alexy R, 'Law, Morality, and the Existence of Human Rights' (2012) 25 Ratio Juris 2.

- The Argument from Injustice: A Reply to Legal Positivism (OUP 2002).

—_, 'Hans Kelsens Begriff des Relativen Apriori' in Alexy and others (eds), Neukantianismus und Rechtsphilosophie (n 46).

Austin J, The Province of Jurisprudence Determined (Wilfrid E Rumble ed, Cambridge University Press 1995).

Bentham J, An Introduction to the Principles of Morals and Legislation (1781) (Batoche Books 2000).

- - A Fragment on Government (with an introduction by FC Montague) (Clarendon Press 1891).

Cohen Jonathan, Hart HLA, 'Symposium: Theory and Definition in Jurisprudence' (1955) 29 Proceedings of the Aristotelian Society, Supplementary Volumes 213.

Beyleveld Deryck and Brownsword Roger, 'Methodological Syncretism in Kelsen's Pure Theory of Law' in Paulson and Litschewski Paulson (eds) (n 40).

Coleman J, 'Beyond the Separability Thesis: Moral Semantics and the Methodology of Jurisprudence' (2007) 27 OJLS.

_ Juris.

_- 'The Architecture of Jurisprudence' (2012) 121 The Yale Law Journal.

Delacroix Sylvie, Legal Norms and Normativity - An Essay in Genealogy (Hart Publishing 2006).

Dickson J, Evaluation and Legal Theory (Hart Publishing 2001).

Finnis J, Natural Law and Natural Rights (2nd edn, OUP 2011). 
IS LEGAL POSITIVISM TENABLE BEYOND MORAL RELATIVISM?

Gardner J, 'Legal Positivism: 51/2 Myths' (2001) 46 The American Journal of Jurisprudence.

Hammer Stefan, 'A Neo-Kantian Theory of Legal Knowledge in Kelsen's Pure Theory of Law? in Paulson and Litschewski Paulson (eds) (n 40).

Harman Gilbert, 'What is Moral Relativism?' in Explaining Value and Other Essays in Moral Philosophy (Clarendon Press 2000).

, 'Moral Relativism' in Gilbert Harman and Judith Jarvis Thomson, Moral Relativism and Moral Objectivity (Blackwell Publishers 1996).

Hart HLA, 'Kelsen Visited' (1963) 10 UCLA Law Review 709,

, The Concept of Law (With an Introduction by Leslie Green and a Postscript edited by Penelope A. Bulloch and Joseph Raz) (3rd edn, Clarendon Press 2012).

, 'Positivism and the Separation of Law and Morals' in Essays in Jurisprudence and Philosophy (Clarendon Press 1983).

, 'Natural Rights: Bentham and John Stuart Mill' in Essays on Bentham - Studies in Jurisprudence and Political Theory (Clarendon Press 1982).

, 'Definition and Theory in Jurisprudence', in Essays (n 78).

Jovanović Miodrag, Collective Rights - A Legal Theory (Cambridge University Press 2012).

Kelsen Hans, "Foreword" to the Second Printing of Main Problems in the Theory of Public Law' in Stanley L Paulson and Bonnie Litschewski Paulson (eds), Normativity and Norms - Critical Perspectives on Kelsenian Themes (Clarendon Press 1998).

- Pure Theory of Law (Max Knight tr, University of California Press 1967). 


\section{Miodrag JOVANOVIĆ}

- 'Value Judgments in the Science of Law' in What is Justice? Justice, Law, and Politics in the Mirror of Science (University of California Press 1971).

, 'Causality and Imputation' (1950) 61 Ethics 1, 6.

, 'Politics, Ethics, Religion and Law' in Gerhard A Ritter and Gilbert Ziebura (eds), Faktoren der politischen Entscheidung - Festgabe für Ernst Fraenkel zum 65 Geburtstag (Walter de Gruyter \& Co 1963).

- Hauptprobleme der Staatsrechtslehre (JCB Mohr 1911).

- Grenzen zwischen juristischer und soziologischer Methode (JCB Mohr 1911).

- 'The Pure Theory of Law and Analytical Jurisprudence' (1941) 55 Harvard Law Review 44.

, General Theory of Law and State (Harvard University Press 1949).

, 'Naturrechtslehre und Rechtspositivismus' in Friedrich Koja (ed), Hans Kelsen oder Die Reinheit der Rehtslehre (Böhlau Verlag 1988).

- Introduction to the Problems of Legal Theory (translation of the first edition of the Reine Rechtslehre, by BL Paulson and SL Paulson) (Clarendon Press 1992).

- 'Law, State and Justice in the Pure Theory of Law' (1948) 57 The Yale Law Journal 377.

- 'Natural Law Theory and Legal Positivism' in General Theory of Law and State (n 54).

- 'Absolutism and Relativism in Philosophy and Politics' (1948) 42 The American Political Science Review 906.

, 'Science and Politics' (1951) 45 The American Political Science Review 641. 
IS LEGAL POSITIVISM TENABLE BEYOND MORAL RELATIVISM?

- 'Law and Morality', in Hans Kelsen, Essays in Legal and Moral Philosophy (selected and introduced by Ota Weinberger) (Petar Heath tr, D Reidel 1973).

- 'The Natural Law Doctrine Before the Tribunal of Science' (1949) 2 The Western Political Quarterly.

Kersting Wolfgang, 'Neukantianische Rechtsbegründung. Rechtsbegriff und richitges Recht bei Cohen, Stammler und Kelsen' in Robert Alexy and others (eds), Neukantianismus und Rechtsphilosophie (Nomos 2002).

Leiter B, 'The Demarcation Problem in Jurisprudence: A New Case for Skepticism' (2011) 31 OJLS.

Maccormick N and Weinberger Ota, An Institutional Theory of Law - New Approaches to Legal Positivism (D Reidel Publishing Company 1986).

Marmor A, Positive Law and Objective Values (OUP 2001).

- , 'Farewell to Conceptual Analysis (in Jurisprudence)' in Wil Waluchow and Stefan Sciaraffa (eds.), Philosophical Foundations to the Nature of Law (OUP 2013).

Mead Margaret, 'Some Anthropological Considerations Concerning Natural Law' (1961) 6 Natural Law Forum 51.

Owen Brink David, Moral Realism and the Foundation of Ethics (Cambridge University Press 1989).

Pettit Philip, 'Substantive Moral Theory' (2008) 25 Social Philosophy and Policy.

Paulson Stanley, 'On the Puzzle Surrounding Hans Kelsen's Basic Norm’ (2000) 13 Ratio Juris 279.

Priel Dan, 'Jurisprudence Between Science and the Humanities' (2012) 4 Washington University Jurisprudence Review.

Radbruch G, Rechtsphilosophie (7th edn, KF Koehler Verlag 1970). 


\section{Miodrag JOVANOVIĆ}

Raz J, 'The Argument from Justice, or How Not to Reply to Legal Positivism', in The Authority of Law-Essays on Law and Morality (2nd edn, OUP 2009).

- 'The Purity of the Pure Theory', in The Authority of Law (n 4).

- 'About Morality and the Nature of Law' in Between Authority and Interpretation - On the Theory of Law and Practical Reason (OUP 2009).

Röhl Klaus, Allgemeine Rechtslehre (Carl Heymanns Verlag 2001).

Rüthers Bernd, Rechtstheorie (3rd edn, CH Beck 2007).

Shapiro S, Legality (The Belknap Press of Harvard University Press 2011).

Spaak Torben, 'Kelsen and Hart on the Normativity of Law' (2005) 48 Scandinavian Studies in Law.

- 'Meta-Ethics and Legal Theory: The Case of Gustav Radbruch' (2009) 28 Law and Philosophy 261.

Tasioulas John, 'The Legal Relevance of Ethical Objectivity' (2002) 47 The American Journal of Jurisprudence.

Toh Kevin, 'Hart's Expressivism and his Benthamite Project' (2005) 11 Legal Theory.

Waldron J, 'The Irrelevance of Moral Objectivity', in Robert P George (ed), Natural Law Theory - Contemporary Essays (OUP 1992).

Wong David, Natural Moralities - A Defense of Pluralistic Relativism (OUP 2006).

Chris Gowans, 'Moral Relativism', in Edward N Zalta (ed), The Stanford Encyclopedia of Philosophy (2008) http: //plato.stanford.edu/entries/moral-relativism/ accessed 5 February 2013). 
IS LEGAL POSITIVISM TENABLE BEYOND MORAL RELATIVISM?

Green L, 'Legal Positivism', in Edward N Zalta (ed), The Stanford Encyclopedia of Philosophy (Winter 2003 Edition) http://plato.stanford.edu/entries/legal-positivism/ accessed 5 February 2013.

Van Roojen Mark, 'Moral Cognitivism vs. Moral Non-Cognitivism' in Edward N Zalta (ed), Stanford Encyclopedia of Philosophy (Summer 2009) http://plato.stanford. edu/entries/moral-cognitivism/\#NonRel? accessed 5 February 2013. 
Este libro forma parte del acervo de la Biblioteca Jurídica Virtual del Instituto de Investigaciones Jurídicas de la UNAM www.juridicas.unam.mx

http://biblio.juridicas.unam.mx 